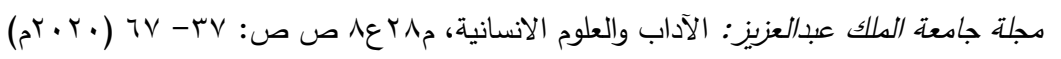

DOI:10.4197/Art.28-8.3

\title{
تلاقي الكتابات الفرانكفونية والعربية في الأدب المغاربي: الرواية أنموذجا
}

\author{
عبدالله أحمد الغامدي \\ جامعة الملك عبد العزيز \\ كلية الآداب والعلوم الإنسانية
}

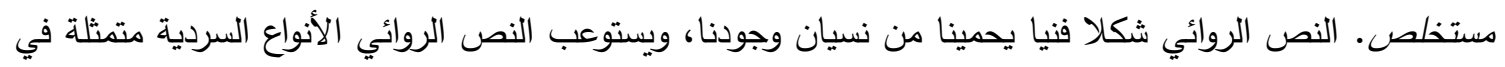

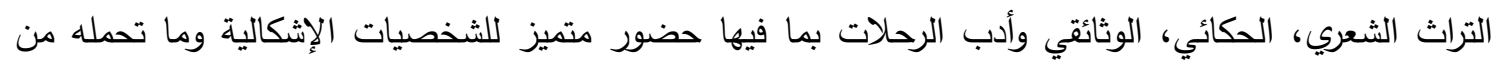

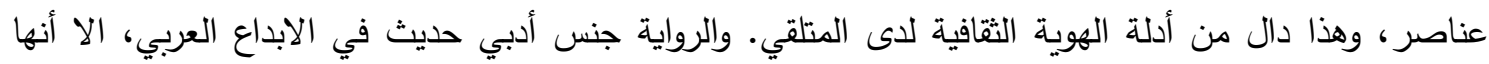

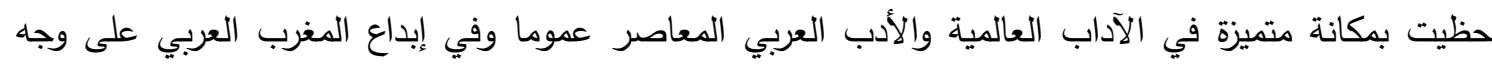

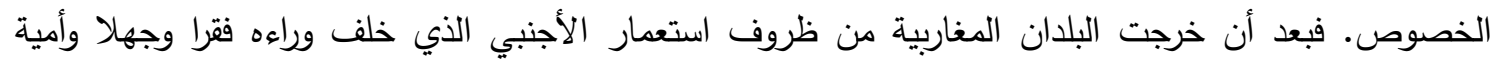

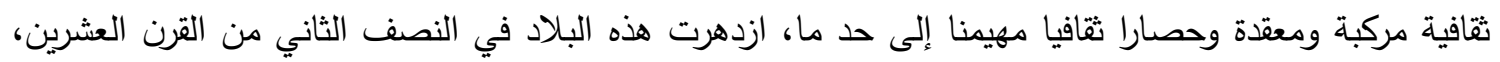

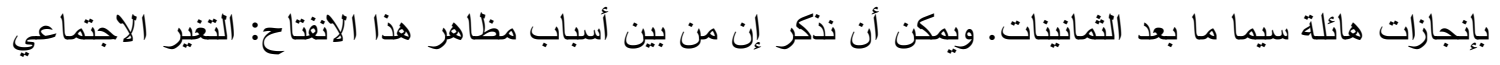
الذي طرأ على هذه البلاد بعد الاستقلال نتيجة "تعبير الرواية عن فئة اجتماعية جديدة من المثقين: كتابن كتابا وقراء."

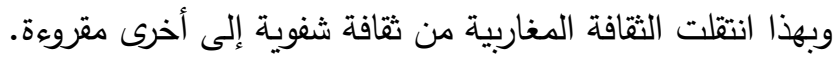
البلاد المغاربية ذات موقع متميز جمع بين مختلف الحضارات. وقد منحتها هذه المكانة أهمية قصوى وثراء بناء

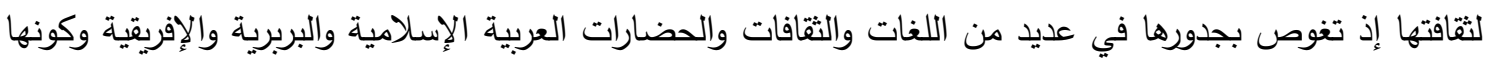

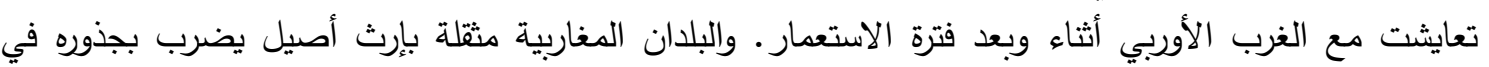

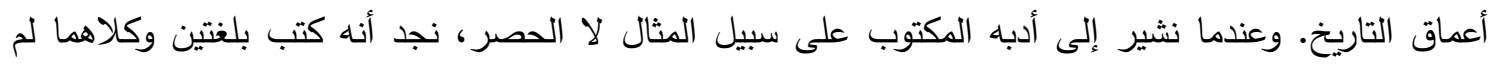
تتفصل عن أصولها العربية الإسلامية: لغة، دينا، حضارة وإرثا أصيلا.

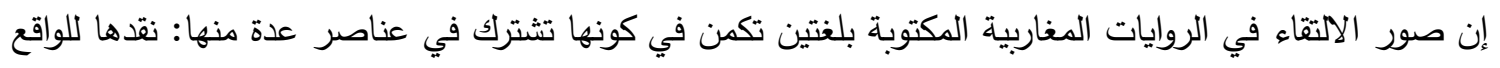
الاجتماعي المغاربي وإبراز عنصر علاقتها مع المجتمع الغربي بمختلف أشكاله. وإن لم يعترف كثيرا من المفكرين

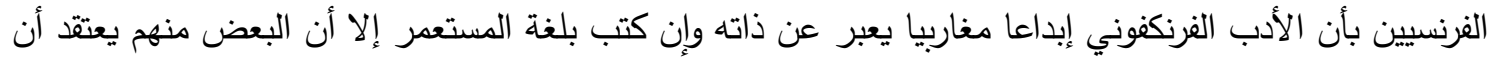

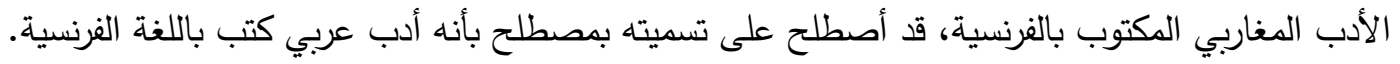

واطلقت على هذا الإبداع العربي المكتوب بالفرنسية

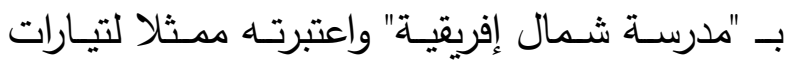

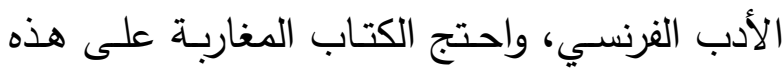
التسمية و وافقهم على ذلك بعض النقاد الفرنسيين

\section{المقدمة}

تثار حول هويـة الأدب المغاربي المكتوب بالفرنسية

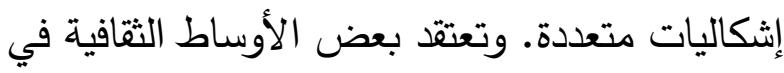

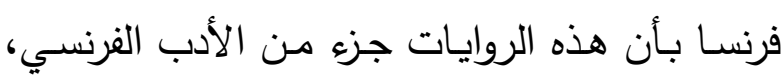


الفرنسيين الذين يكتبون بالفرنسية، وفرقوا بين الأدب

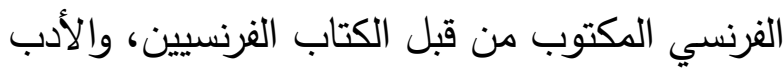
الفرنسي المكتوب من قبل الكتاب الأفارقة أو غيرهم

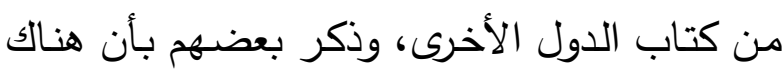

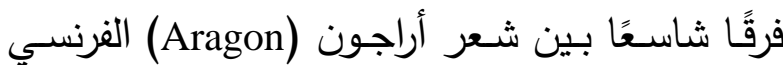

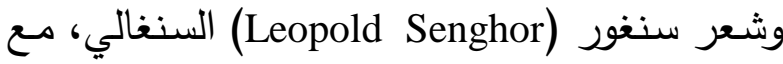
اشتراكهما في لغة الكتابة، كما أن ثمة اختلافا بين

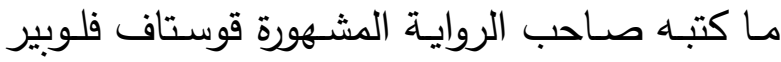

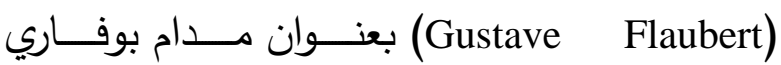
ومـا كتبـه الجزائري مولـود فرعون في رواية: "الدروب الوعرة" ( Les Chemins

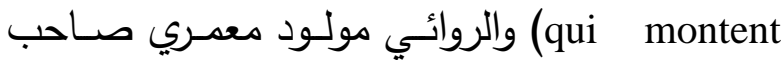

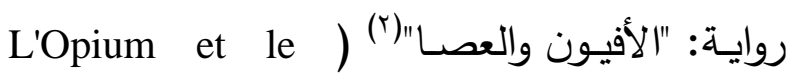
Baton الأدب وهويته سيؤدي إلى إنكار آداب أمم استعارت

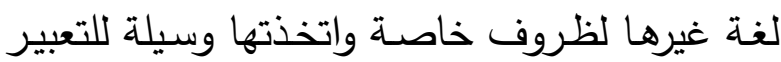
عن أفكارها ومشاعرها؛ إذ إن أفكار أمة ومشاعرها

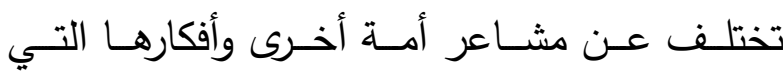
استعارت منها لغتها.(ץ) هناك من يرفض أن تعد الأعمال الروائية المكتوبة

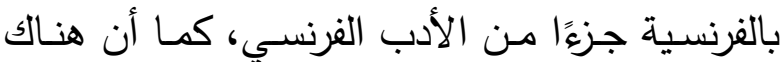

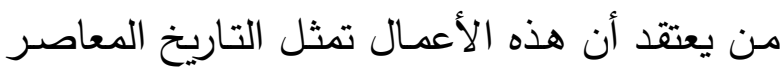

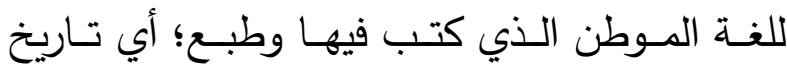

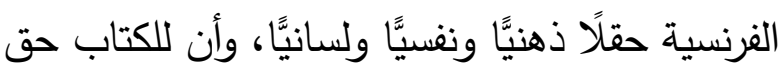
المواطنــة الأدبيــة الفرنسـية كالكتــاب الفرنسـيـين

(r) راجع د. محمد غنيمي هلال، دار نهضة مصر، القاهرة (د.ت) من

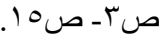

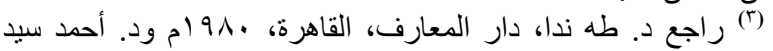

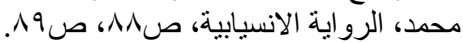

واعتبروها ضدن الإبداعات العربية المغاربية، ومثال

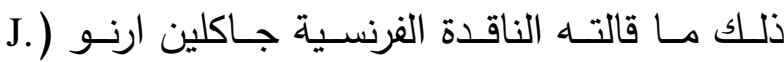

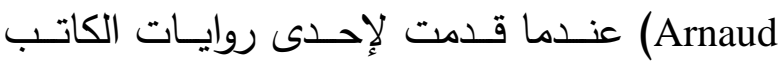
الجزائري كاتب ياسين: "علينا أن نعد هذا الكتاب روايـة عربيـة مترجمـة إلى اللغـة الفرنسية، لا لأن

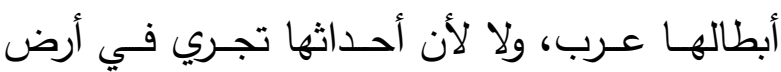

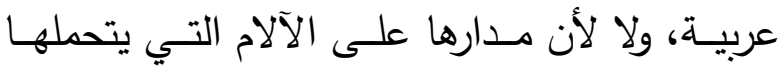

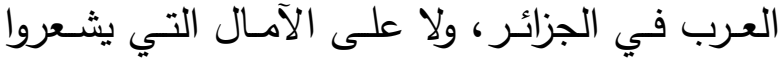

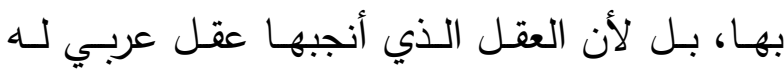

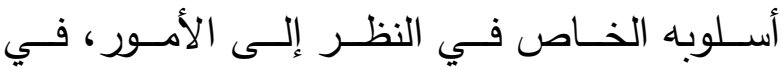
الإحسـاس بالمشككلات، في معانـاة الحيـاة، وفي الإسي تصور الزمان والمكان"(1) تثير مسـألة نسـبة الأدب وانتمائهـه لـلآداب الأخـرى دارسي الأدب المقارن وتحفزهم إلى البحث في هذا الموضوع؛ فبعضهم يعود للتراث العربي القديم الذي الذي البه يضم نماذج من الكتّاب مزدوجي اللغة كعبدالحميد الكاتب وعماد الدين الأصفهاني، وكذلك لدى الأمم الأخرى كـ (مير) شـاعر الغزل في اللغـة الأرديـة،

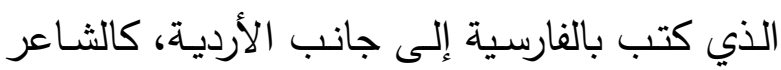

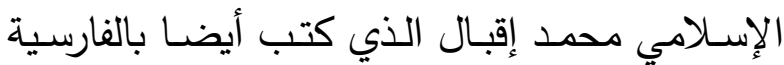
والأرديـة، ومـا كتبـه الكاتب الروسي هنري ترويـات الريات باللغـة الفرنسـية عـن قضـايا (Henri Troyat) المجتمع الفرنسي ومشكلاته... وبعضهم يعتقدون أن لغة النص هي هويته، ولهذا

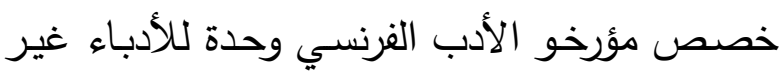

Jacqueline Arnaud, La littérature maghrébine de langue française, Paris, 1er V., Ed. Publisud, 1986, p. 252. أنظر كذلك، كفافي، محمد عبد السلام، في الأدب المقارن دراسات في

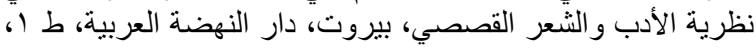

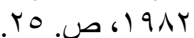


يطحن مفاهيم أوروبية على نحو بالغ العبث" ل، وهو ذاته صـاحب العبارة الثهيرة "إن أرواحنا تنزف دماً في فرنسا"،. ويعتقد أن أبلغ تعبير إزاء الفرنسية جاء على لسـان كاتـب ياسـين الـذي قـال: "إن معظـم ذكريـاتي وإحساسـاتي وأحلامسي ومناجـاتي الداخليـة تتعلـق بـبلادي، فــن الطبيعـي أن أثـعر بهـا في واهي

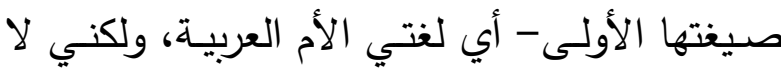

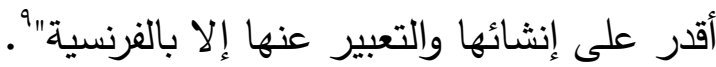
كما أن هنالك من يدعم هذا القول؛ إذ عبرت بعض

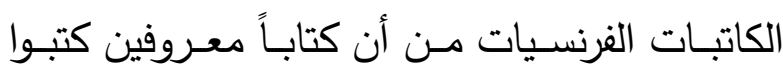
بلغات ليست لغاتهم، كيونسكو (Eugene Ionesco)، كتـب بالفرنسـية، وجـويس (James Joyce) وكافكـا كتبـا بالإنجليزيـة. ولكن ثــة مـن (Franz Kafka) يرى بأن الفارق بين الفرنسية والعربية فارق جوهري بينما تشترك اللغات التي كتب بها هؤلاء المشاهير مـع لغـاتهم الأصـلية. وشـريحة مسن هـؤلاء يقدمون

> يقول الكاتب الفرنسي "ألبير كامو" عن اللغة الفرنسية: "اللغة الفرنسية هي وطني"، وكتب الجز ائري "مالك حدادي لتادي في كتابه (الأصفار

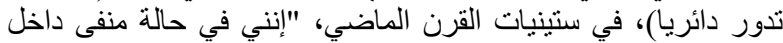

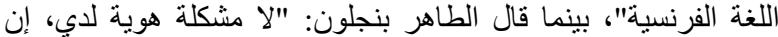

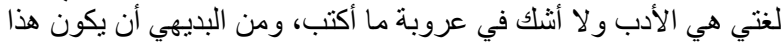
الأدب الذي أكتبه عربيا في الجوهر و الروحح، وليس في الكتابة"، اللغة الكنة

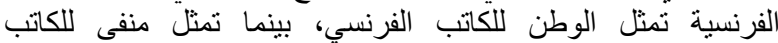

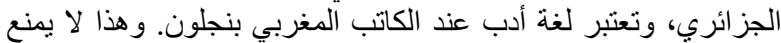

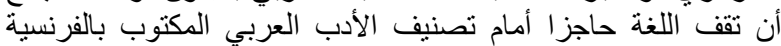

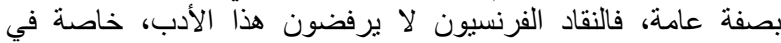

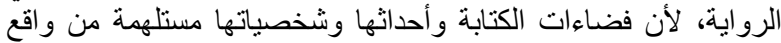

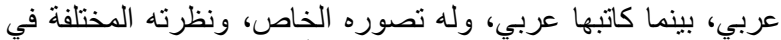

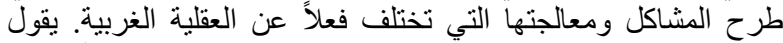

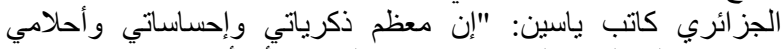

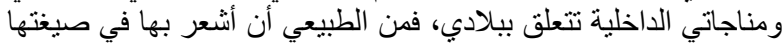

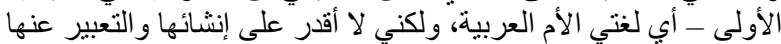

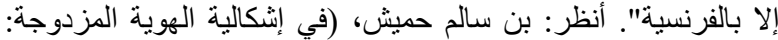

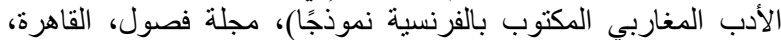

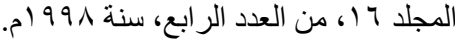

${ }^{8}$ D. Chraïbi, L’Âne, Paris, éd. Denoël, 1959, pp. 13-14.

$$
\text { 9 المرجع السابق ذاته، بن سالم حميش، منشور في مجلة فصول. }
$$

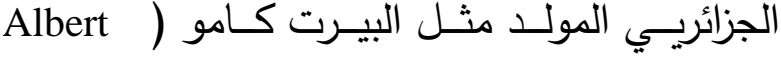
(Camus ) وجـان سـيناك (Jean Sénac) وغيـرهم، والأعمـال الروائيـة لا يمكـن نسـبتها إلـى العربيـة بوصفها غنيمـة حرب، كمـا يقول الكاتب الجزائري كاتب ياسين. ؛ أمـا اللغة فهي عالم في ذاتها تعطي للخطـاب قواعـده وأنظمتـه، وتقــدم للكتابـة أرضـية

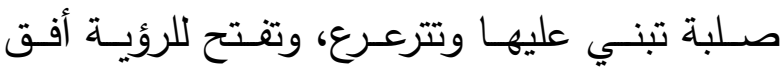
نبضها وتحركها، فاللغة ليست مجرد مرافق، بل هي خيط عميق الحبكة ونسيج الفكر ، إنها للفرد كنز الذاكرة والوعي اليقظ. إن أوجـهـ الإشـكالات في الأدب المغـاربي متعـددة وخاصـة لدى الكتاب العرب الجزائرين الذين كتبوا بالغرنسية، إذ يعتقدون بأنهم منفيين عن لغتهم الأم، ويشعرون بأن اللغة الفرنسية التي يتقنوها قد فرضها

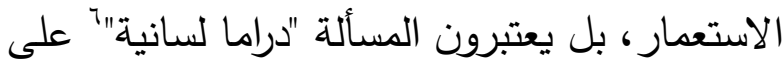
حد تعبيـر ألبيـر ميهـي (Albert Memi)، وحالـة استلاب لغوي كما عبر عن ذلك أحمد الصفريوي Jean ) وجــــــــــــــــــ (Ahmed Sefrioui) (Amrouche وكاتــبـ ياســين (Kateb Yacine) وإدريس الشرابي (Driss Chraibi). يقول شراييبي: "منذ عشر سنوات ودماغي العربي المفكر بالعربية

${ }^{4}$ Littérature francophone, Anthologie, écrite par un ensemble de professeurs francophones sous la direction de Jean-Louis Joubert, Paris, éd. Nathan et la participation de l'Agence de Coopération Culturelle et Technique, 1992, P. 316 " بن سالم حميش، في معرفة الآخر ، دار الحوار للطباعة والنشر

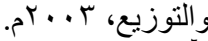
"سعيد يقطين، تحليل الخطاب الروائي: الزمن ـ السرد ـ التبئير، المركز

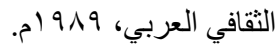


المتوسطي". " بينما هناك ممارسة استعلائية تحث الكتّاب العرب على ممارسـة الثقافة الفرنسية وحمل

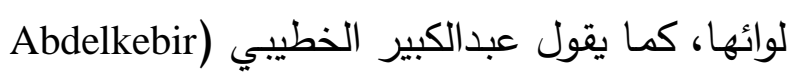
(Khatibi يعتقد بضـف تأثير الفرنسية في المغرب العربي لئي

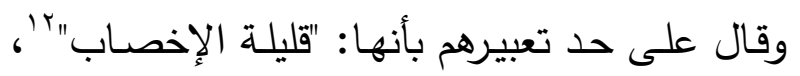

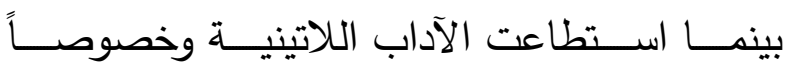
الأسبانية إخصاب قارة أمريكا الجنوبية بأكملها.

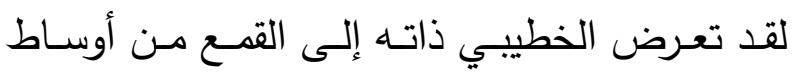

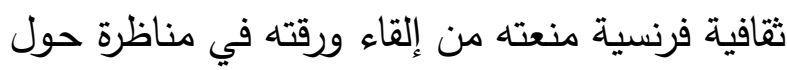

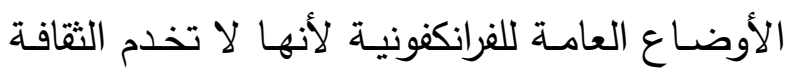

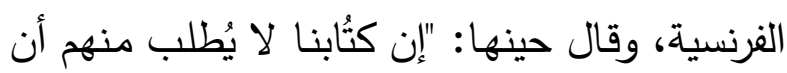

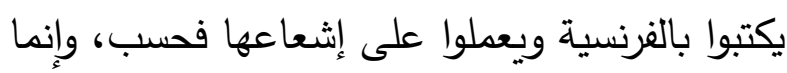
كذلك أن يكونـوا خدّام الأعتـاب الفرانكفونيـة نظامـاً

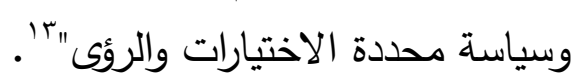

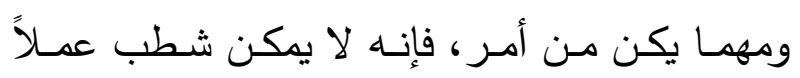

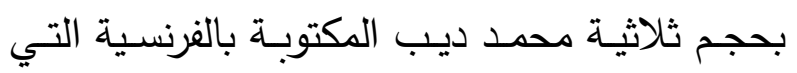

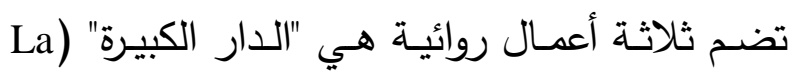
Grande Maison

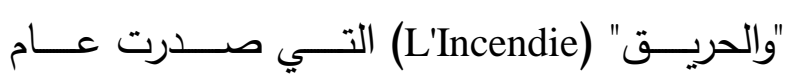

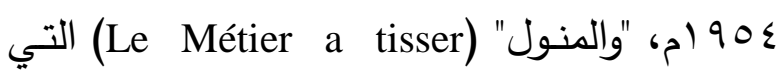
نشرت عام 90 ام، فقد كانت أشبه بثلاثية نجيب

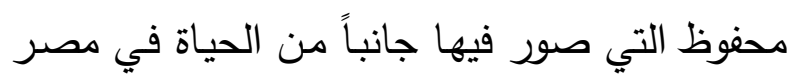

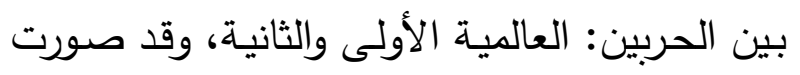

${ }^{11}$ Malek Haddad, Les Zéros tournent en rond (essai), Maspero, 1961.

${ }^{12}$ A. Khatibi, Le roman maghrébin, Maroc, éd. SMER, 1979, p. 14.

"' انظر: عبدالكبير الخطيب، الرواية المغربية، منشورات المركز

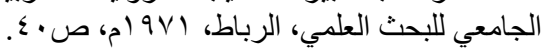

أنفسهم ممثلين لحضارة عشوائية متجذرة في كل ما هو عجيب وغريـب، اسـتجابة لتصـورات المتلقين

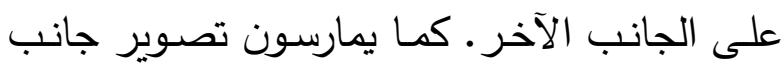

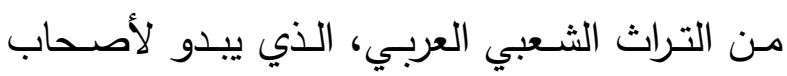

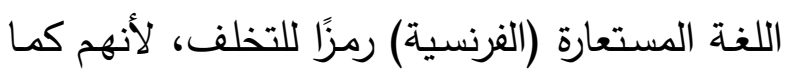
يضنون، يستكثفون تراثاً شفهياً غير مكتوب يوازي التهاري

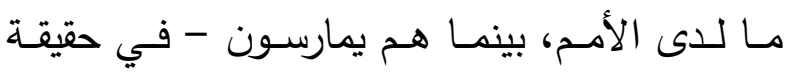

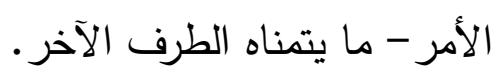

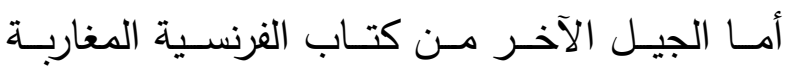

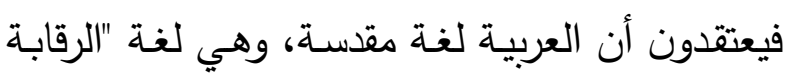

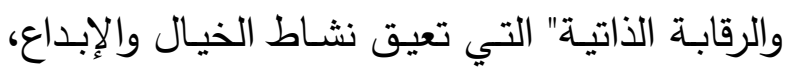

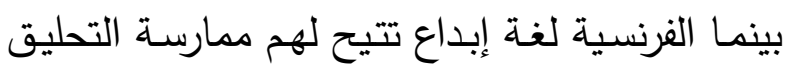
والابتكار ، ويخفوا من خلالها حقيقة مواقفهم الفكرية كما يفعل جمال الدين الثيخ ومحمد أركون وابن جلون وغيرهم. وهناك جيل ينادي بالتعددية ويمتدح الكتابة باللغتين العربية والفرنسية، ويجهل الكثير من وهن

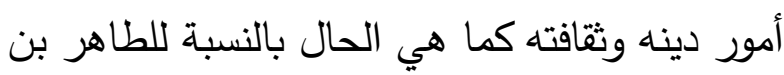
جلون الذي يقول عنـهـ بن سـالم حميش: كثيراً مـا لمال تطلبه وسائل الإعلام الأوروبية عن سذاجة أو رغبة لفية فـي التسـخير مـن أجـل اسـتجوابه فـي الإســلام والحركات الأصسولية وفي الثقافة التي يفتخر بها، التها، "هذا في حين أنه في روايته المجازة (الليلة المقدسة)

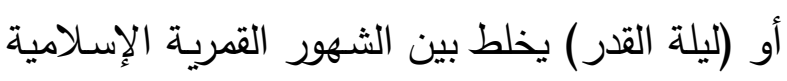

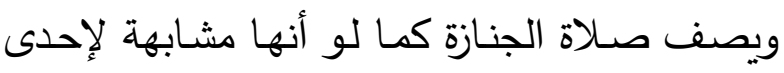

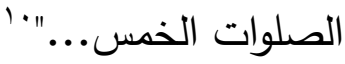

يقول مالك حداد بأن الفرانكفونية قد خيبت الآمال فهـي: "تفصـلني عـن وطنـي أكثـر مـن البحـر ' ' المرجع السابق ذاته، بن سالم حميش، منشور في مجلة فصول. 
الثخصـية الوطنيـة عـن طريـق محاربـة لغتهـا الأم

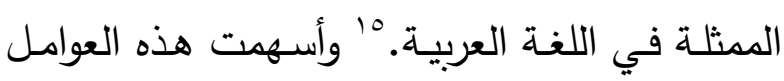
في خلق الازدواجية اللغوية وتتميتها مما أوجد جيلا من الكتاب المغاربة، يتحدثون بلسان أجنبي ويكتبون

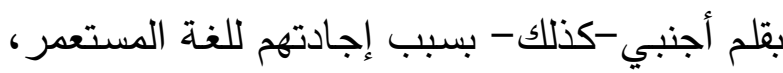
وهذا ما أدى إلى قول أحد الباحثين: لقد ظل معظم

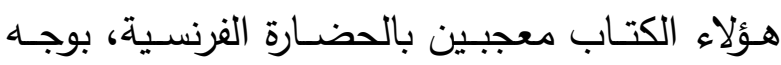

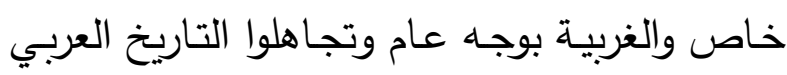
ومعالم الحضـارة الإسلامية، لقد حرموا حسب قوله، "من الإلمام الكافي بلغتهم التي بواسطتها يطلعون الإنسا

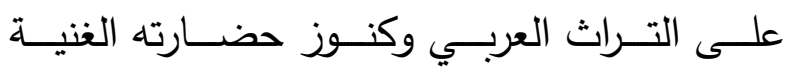

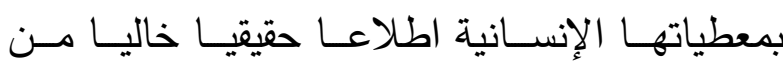

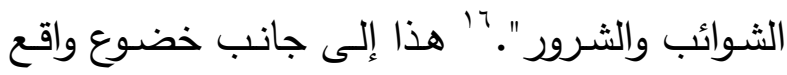
الثتافة للواقع السياسي وتطور في ظروف مأسوية

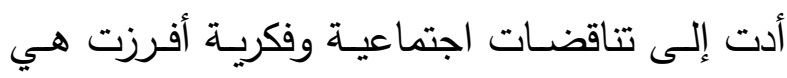

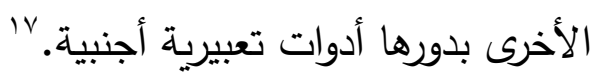

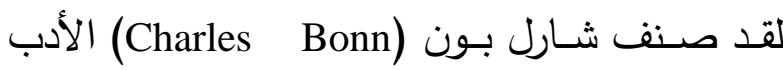

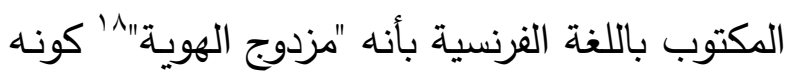
يحمل في داخله وفي الوقت ذاته الهويـة الأوربيـة

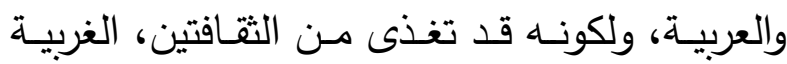

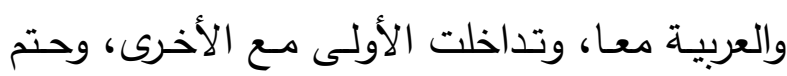

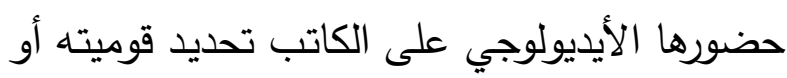

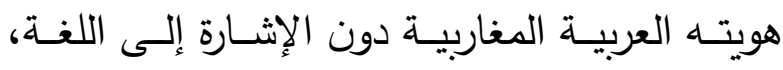

10 بن نعمان، أحمد، التعريب بين المبدأو التطبيق، الجزائر، ش. و. ن.

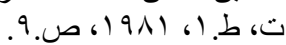

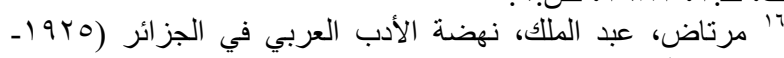

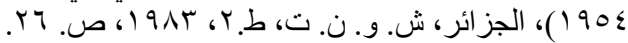
17 BONN, Charles, La Situation Algérienne et conscience nationale. Après l'indépendance; Paris, No (85), Oct-Déc 1986.- p. 36.

${ }^{18}$ Présence francophone, Revue internationale de langue et de littérature, no. 45, 1994.
هذه الثلاثية - بدورها- الحياة في الجزائر خلال ما يقرب من ثلاث سنوات من الحرب العالميـة الثانية

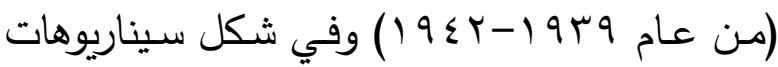
ومشاهد تكشف عن جوهر الحركة الاجتماعية في تلك الحقبة. لقد دارت أحداث رواية محمد ديب في مدينــة تلمســان، فـي دار سـبيطار علـى الحـدود دارد المغربية الجزائريـة، التي وصفها الكاتب بأنها تشبه البلدة في اتساعها وعدد سكانها. وهذه الدار عبارة عن بيت عتيق موقوف على سكان همهم الاقتصاد

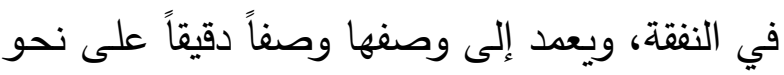

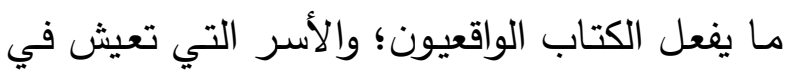

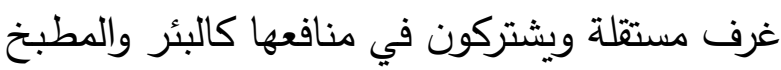
ودورة المياه، وهذه الدار تضم نمـاذج بشرية بائسـة

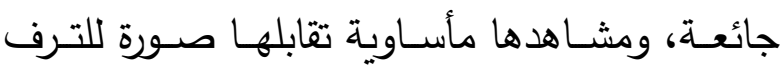

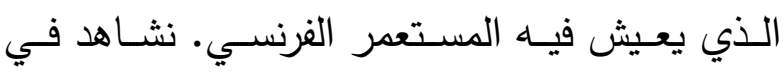

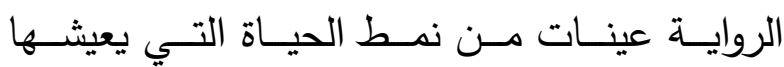

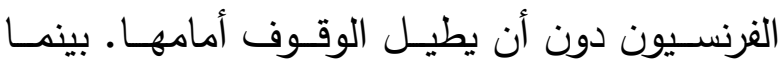

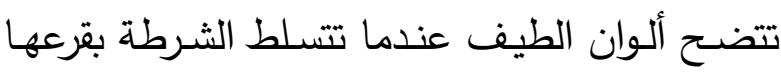
باب دار سبيطار باحثة عن الخارجين على سلطة

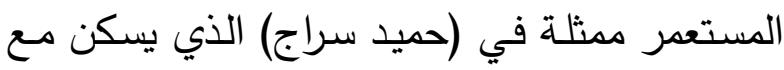

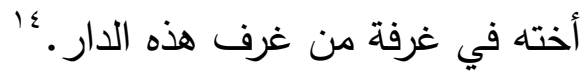

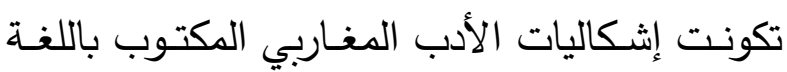
الفرنسية، نتيجة لأسباب أدت إلى الازدواجية اللغوية الادية

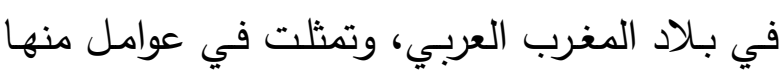

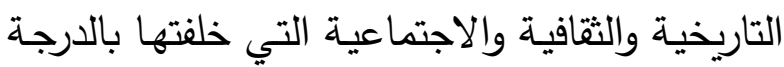

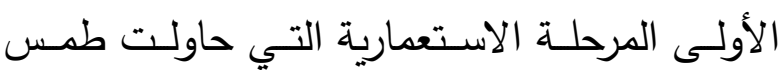

14 Jeanne-Marie Clerc, Assia Djebar: Ecrire, Transgresser, Résister, éd. L’Harmattan, 1997, P. 74 
قولدمان (Goldmann) بأن الرواية الحديثة: "بحث

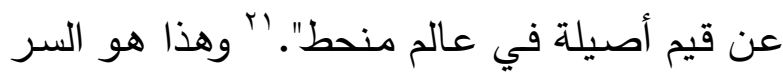

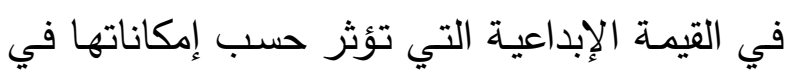
الواقع الملموس للشعوب.

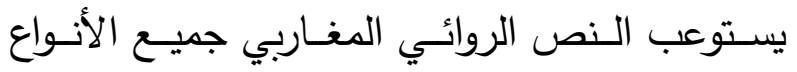

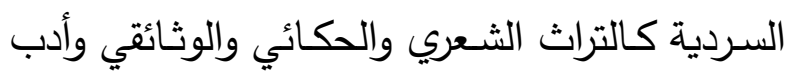
الرحلات، كما لشخصياتها حضور متميز بما تحمله

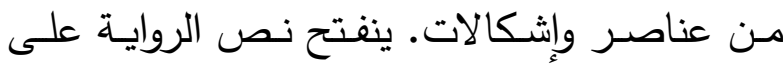
أشكال ثقافـة شعبية متعددة كالمعتقدات والظواهر

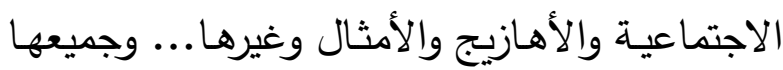

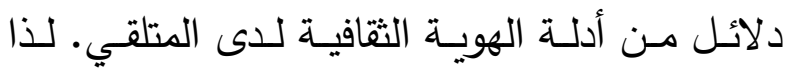
تمتاز الرواية المغاربية في نصيها العربي والفرنسي بتعـدد الثخصـيات ووفـرة المحكيـات والأحـــاث. الرواية المغاربية المكتوبة بلغتين، جنس أدبي حديث

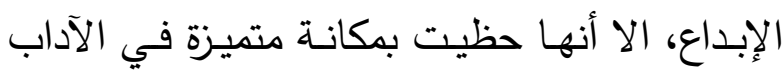

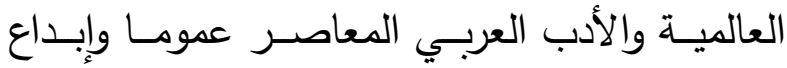

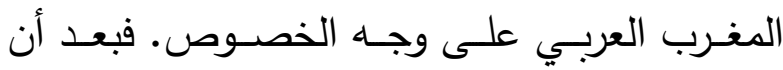

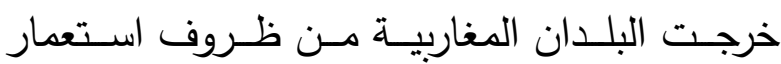

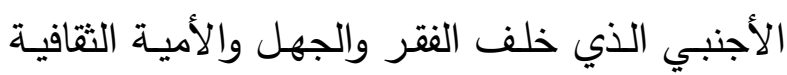

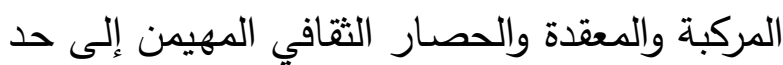
ما، ازدهرت هذه البلاد في النصف الثاني من القرن

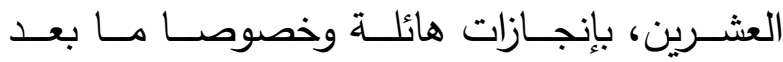

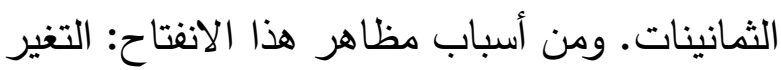
الاجتماعي الذي طرأ على هذه البلاد بعد الاستقلال

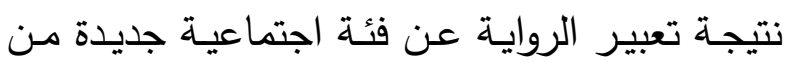

${ }^{21}$ L. Goldmann, Pour une sociologie du roman, [compterendu]; Revue française de sociologie; Année 1965; 2-6 pp. 251-252.
وأصبح للتحديد معنى في حضور العنصر الأجنبي المتمثل في اللغة العربية وثقافتها. 19

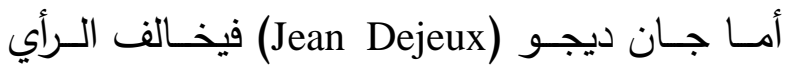

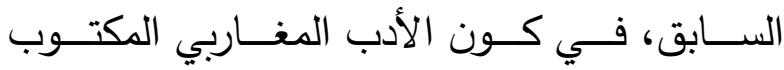

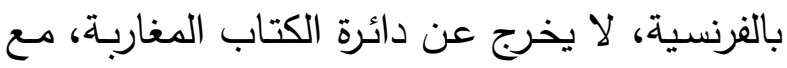
تشبعه بالثقافة الغربية، ومما يزيد رأيه ثبوتا تصريحه

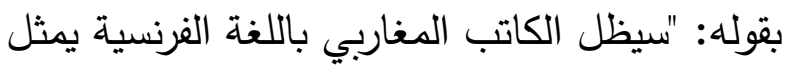

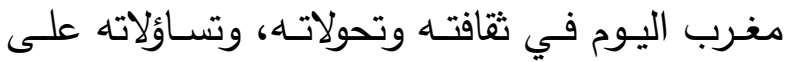

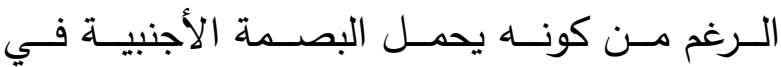
كتاباته" ‘. وقد أدرج ديجو، الأدب الجزائري - مثالا

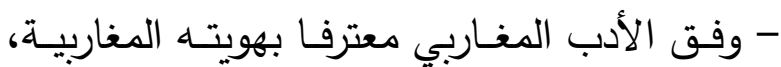

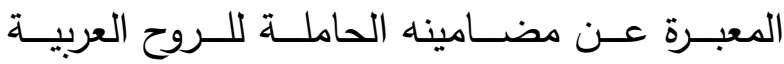
المغاربية التي تثبت هويته. النصوص الروائية المغاربية: للنص الروائسي المغـاربي اليوم شكل فنـي ووسيلة

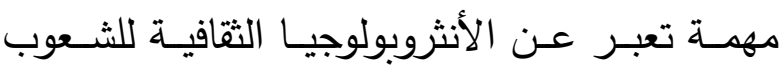

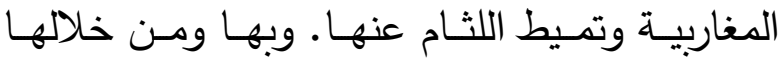

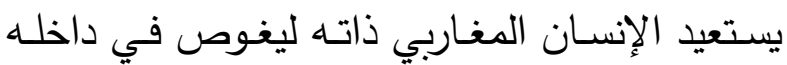

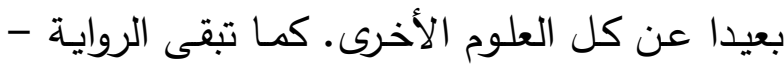

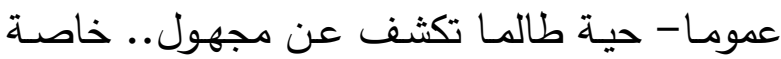
أنها نص سردي يتسم بالرحابة وبقدرتها على تحويل

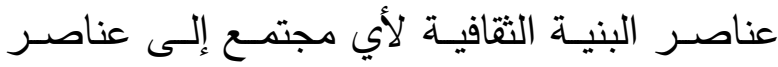

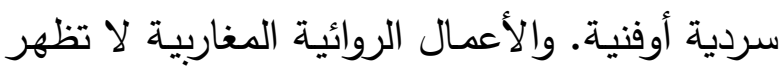
للعيان إلا عندما تستاء مـن قيم مجتمعها وتطمسح

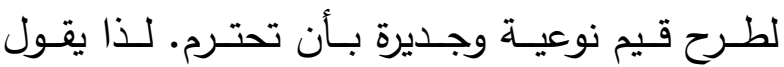

\footnotetext{
${ }^{19}$ Déjeux,J. Situation de la littératures Maghrébine de langue Française.- Alger, Ed. OPU, 1982. p. 184.

20 Déjeux,J. La littérature maghrébine d'expression française, Paris, Puf. Que sais-je ? 1992, p. 3.
} 
متأخرة وهذا ما يصوره لنا دريس شرايبي في روايته (Les Boucs) عنـدما قـرر المسـتعمر فـرض ثقافتــة فـي الـبلاد المسـتعمرة. إذ عبـر عنـه بعنـف مـن خـلال مقاومـة الشخصيات البطولية وبروز ظاهرة الثرف الذي لا يقبل أن يدنس. ولهذا كتب بعض المبدعين المغاربة بلغتين ليثبتوا للمستعمر وجودهم ويطالبوا بحقوقهم في الاسـتقلال مـع إثبات هـيتهم العربيـة المغاربيـة المسلمة وتأصيل حسهم الوطني والقومي في عديد من الروايات. ولحداثـة عهـد التجربــة الروائيــة المغاربيـة مقارنــة بنظيراتها في المشـرق، يعلل بوشوشـة إقبال كتاب المغرب العربي "على التجريب، وتشكلها على رمال متحركة، جعلت ارتحالاتها تتعدد من اتجاه لآخر، ممـا نوع تحولاتهـا البنيويـة والدلاليـة، ومكَّنها من أن تصوغ أسئلتها الخاصـة التي تشكل العلامـات الدالة على خصوصـيتها، وتسـتمد منهـا ملامـح حداثتها وسط تراكمات الجنس الروائي العربي." "گr ويضيف بأن تنوع الكتابة المغاربية مرتبطة "بسيرورة الروايـة العربيـة فـي المشـرق ومنجـزات الروايـة العالميـة، وخصوصا الفرنسية منها بسبب تواصل تأثير عامل المثاقفـة في كتاب الروايـة المغاربيـة بصسور مختلفـة ونسـب متفاوتـة، ممــا جعل الروايـات التي يبـدعها هؤلاء تكوَّن نتاج ذاكرة سردية عربية مشرقية وغربية

${ }^{23}$ Driss Chraïbi, Les Boucs, Gallimard, 1955.

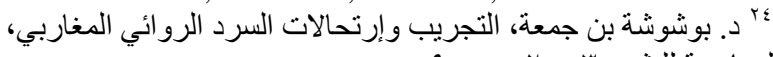

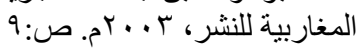

المثقين: سواء الكتاب أو القراء، بُ والتي سعت لنقل الثقافة المغاربية من ثقافة شفوية إلى أخرى مقروءة.

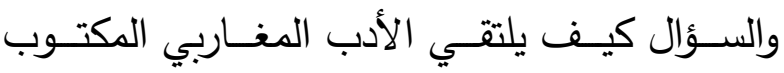
بلغتين؟ وما هي عناصر الالتقاء؟ وهل يتنافران أو يتفقان ولماذا؟ وللإجابة على مثل هذه الأسئلة لا بد من الحديث عن المبدعين المغاربة أنفسهم سواء من ون وله كتب بالفرنسية أو بالعربية.

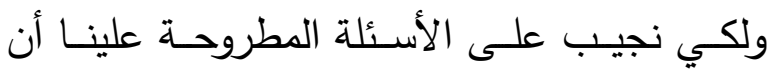
نوضـح بأن البلاد المغاربية ذات موقع متميز جمع بين مختلف الحضـارات. وقد منحتها هذه المكانـة أهمية قصوى وثراء لثقافتها التي تمتد بجدورها في عديــد مـن اللغــات والثقافـات والحضــارات العربيـة الإسـالامية والبربريـة والإفريقيـة وكونها تعايثـت مـع

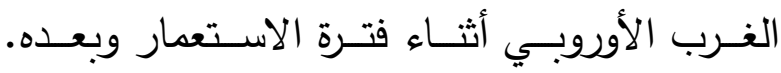
فالبلدان المغاربيـة ذات إرث أصـيل يضـرب بجذوره في أعماق التاريخ. وعند الحديث عن أدبه المكتوب إلبـ على سبيل المثال لا الحصر ، نجد أنه كتب بلغتين وكلاهما لم تتفصل عن أصولها العربية الإسـلامية: لغـة ودينـا وحضـارة وإرثا أصـيلا. ومـن هنـا انقسـم المبدعين المغاربة بين ثقافتين وحضـارتين تمثل كلا منهمـا قيمـة أصسيلة ومعاصـرة اشتقتَّت مـن الحضـارة الغربيـة إلى جانب اللغـة والثقافـة التي أنشأت فكرا جديدا يمكن أن نسميه "بالمثاقفة". أنـتج الكتــاب المغاربــة فـي العصـر الاســتعماري مؤلفات مناهضــة لسياسـة المستعمر فانحرم بعضهمح من حريـة الكتابة ولم يتمكن بعضهم إلا في سنوات

Yr د. بوشوشة بن جمعة، إتجاهات الرواية في المغرب العربي،

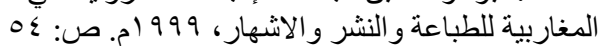


من مواضيع الأدب المغاربي: المثاقفة: تعتبر الرواية المغاربية من أكثر الروايات الرئ

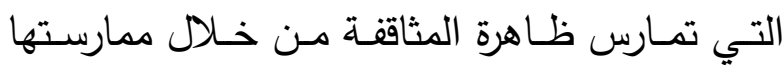

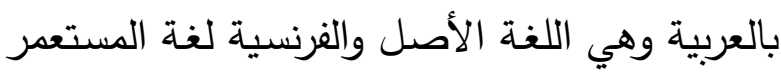
الدخيلة. لذا نجد أن النصوص الروائية المتعددة قد الند

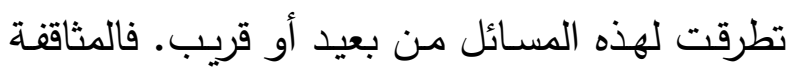
كما نراها، طفت على السطح عبر الأدب المغاربي لئل المكتوب بلغتين. يقول كاتب ياسين: "الفرنكفونيـة

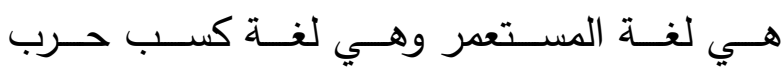

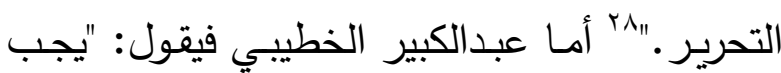

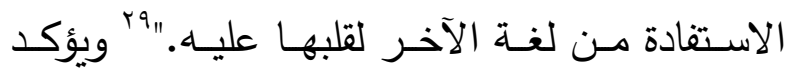
عبداللطيف اللعبي (Abdelatif Lâabi) بأن اللغـة لألة

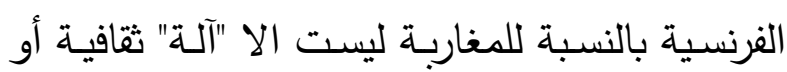

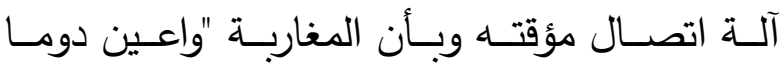

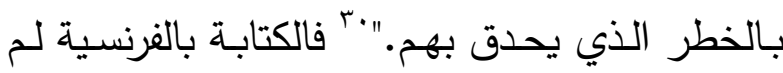
تفرض إلا لظروف استعمارية، فاستخدمت الفرنسية لخدمـة التقافـة والإرث المغـاربي نفسـه. ولهذا تؤكد

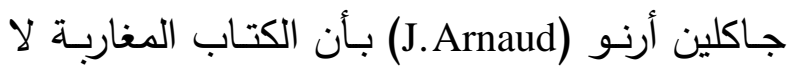

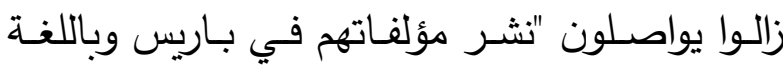

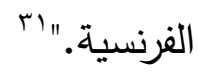

بلدان المغرب العربي بـلاد ديناميكيـة؛ فهي تحافظ

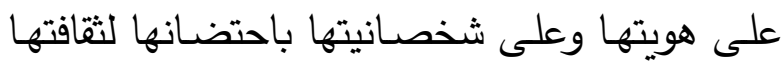

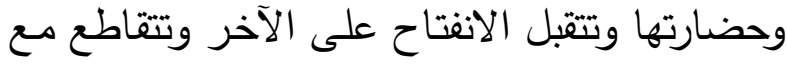

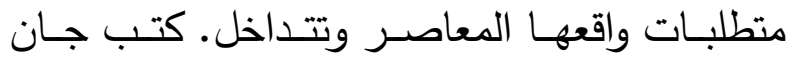
ديجو بأن البحث عن الهويـة في المغرب العربـي

28 Kateb Yacine, La langue de Malek, (in) Nouvel Observateur, ${ }^{\circ} 1157,1987$, p. 87.

${ }^{29}$ A. Khatibi, (in) Le Monde, 17 Décembre 1971.

${ }^{30}$ Abdelatif, Lâabi, Souffles, ${ }^{\circ}$ 18, 1970, p. 36.

${ }^{31}$ J. Arnaud, Op.cit , p. 252.
أوروبيـة، كان لها دورهـا الفاعل في بلورة معالمها

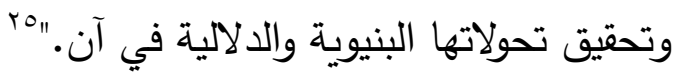
صور الالتقاء في الروايات المغاربية المكتوبة بلغتين

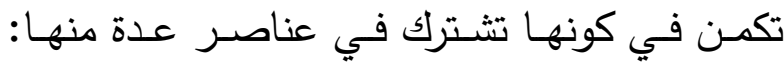

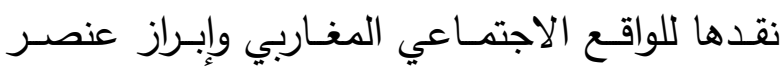

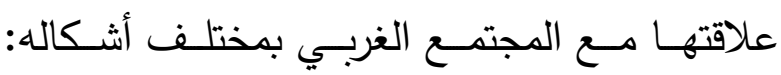

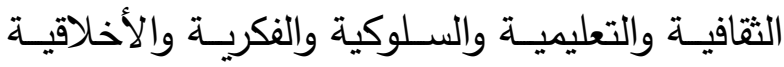

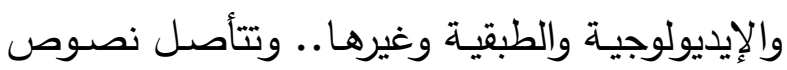

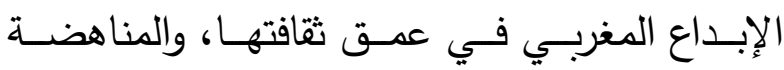
والكفاح والانتفاضـة، انطلاقا بوعي الكتاب بذواتهح ودفاعهم بحسهم الوطني والقومي وذواتهم العربيـة

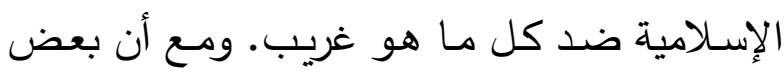

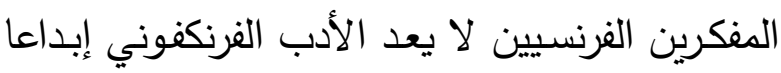

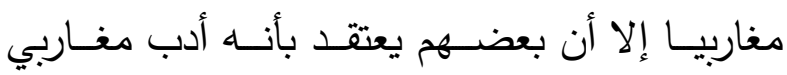

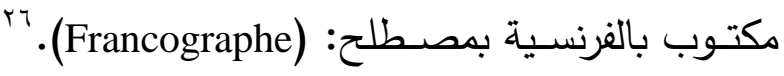

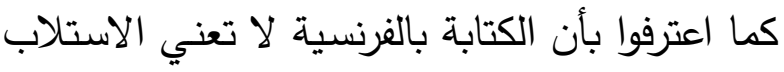

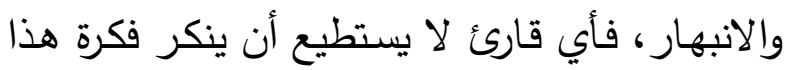

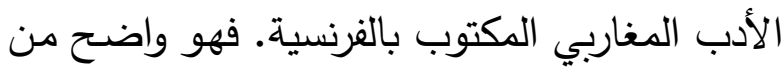

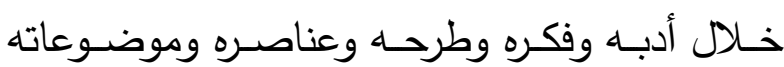

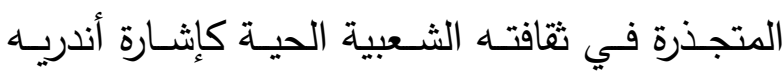
ميكل (André Miquel) عندما يتحدث عن روايات

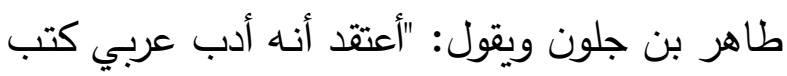

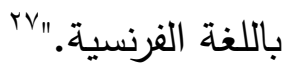

• المرجع السابق نفسه، ص:9 ${ }^{26}$ J. Arnaud, La littérature maghrébine de langue française, Paris, 1er V., Ed. Publisud, 1986, p. 116.

27 André Miquel, La Littérature arabe, Paris, PUF, «Que sais-je?», 1981. 
لشعب غير شعبك والأكثر غرابة أن تكتب لمن هزم

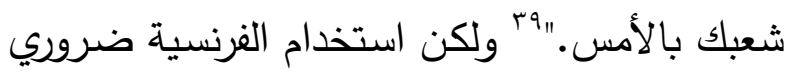

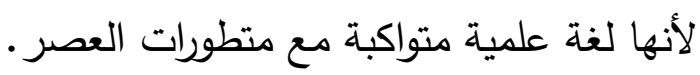
لقـد واصـل الكتـاب المغاربــة إثراء إبـداعهم ونشـره باللغتين العربية والفرنسية، إذ دن المستحيل لمجتمع خارج بعد عقود من الاستعمار ، مواصلة السير على القدمين دون سابق تجربة في مختلف الميادين، من أجل هذا كان على الكتاب الممارسين للغتين تطبيع اللغة الفرنسية مع الموروث الحضاري واستخدام لغة الآخر وسيلة اتصـال في مجتمع حديث ومعاصـر في سـبيل إثبات الهويـة والتعبيـر عنهـا باللغـة الأم التي أستعيدت في مختلف المؤسسـات بعد خروج المستعدر والتي تؤكد بطبيعـة الحال ـ هويتها

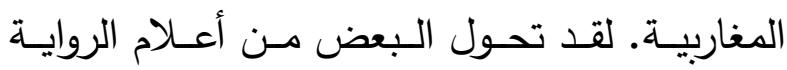
المغاربيــة المكتوبـة بالفرنسـية إلـى الكتابــة باللغــة العربية ومنهم الأديب الجزائري رشيد بوجدرة الذي

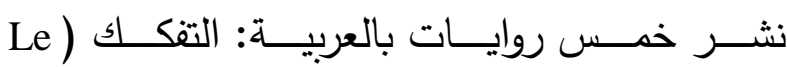
(Lamacération) في (19^rètement

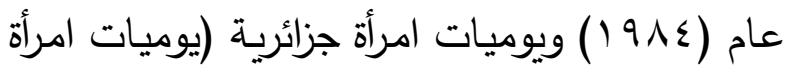
(Les journaux d'une femme algérienne) آرق)

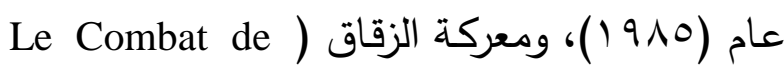

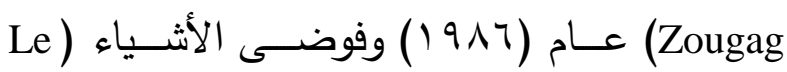
. (Désordre des choses الكتابة والرواية: لا شك أن الشكل يتداخل في كثير من الأحيان في المشاهد الروائية، ولا يمكن للروايـة

\footnotetext{
${ }^{39}$ Albert Memmi, Portrait du colonisé, Paris 1957, pp. 142146, trouvé (in) «Document» à la fin de l'oeuvre de Khatibi, Le roman maghrébin, op. cit. p. 127.
}

شـــاغل رئيســي وبـــأن الكتــاب لا يبـــدعون إلا

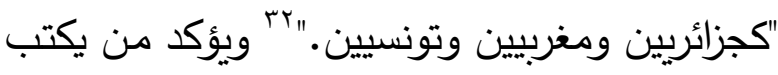
بالفرنسية بـأن الفرنكفونيـة ليسـت بالضـرورة التعلق بها. بَّ فاللغـة العربيـة لغـة ثقافـة ورمز هويـة وطنيـة بينما الفرنسية في الإبـداع لا تمثل الا شـاهد عيان على الأصالة المعاصرة والحديثة للدفاع عن ثقافتهم وتاريخهم وحضارتهم. يعتقد بعض النقاد بأن الإبداع المغاربي عبارة عن وهن وثائق عَ (Documents) أكثر من كونه مؤلفات كما تقول جاكلين أرنو إلا أنها تؤكد: بعدم إلغاء عروبية

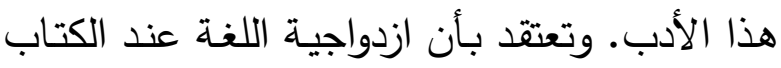
المغاربة هُم ليست عيبا بل إثراء وانفتاحا على الآخر ليسهل فهمه والحوار معهد.. والفرنسية في حد ذاتها

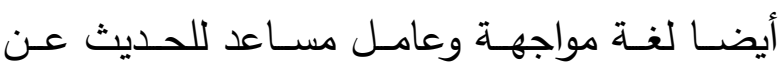

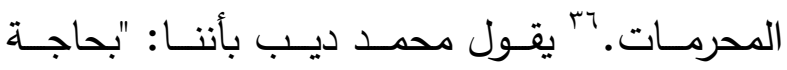
لاستخدام لغـة الآخر لنكتشف أنفسـنا." لَّاستختخدام اللغــة الفرنسـية يســاهم فـي الهـروب مـن الرقابـة

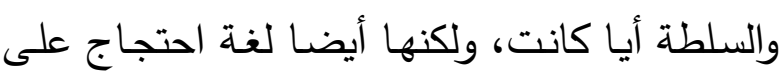
ممارسـة المسـتعمر ومنافسـته وإجبـاره عـل سـماع

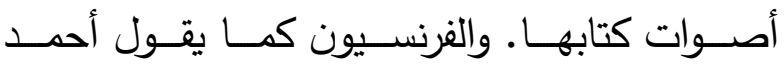

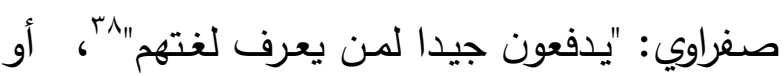

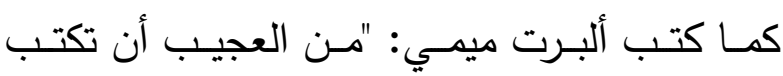

32 J. Déjeux, La littérature maghrébine d'expression française, Paris, Puf. Que sais-je ? 1992, p. 3.

${ }^{33}$ J. Déjeux, op. cit., p. 102.

${ }^{34}$ J. Arnaud, op. cit., p. 11.

35 J. Arnaud, op. cit., p. 11."Il ne fallait pas escamoter l'arabité de cette littérature."

${ }^{36}$ J. Arnaud, op. cit., p. 11."Le français rend possible la transgression de tous les tabous."

${ }^{37}$ Entretien avec Mohamed Dib, cité par Jean Pélagri le 11 Février 1983, (in) «Revue CELFA».

38 Ahmed Sefrioui, La Boite à Merveilles, Paris, Le Seuil, 1954. 


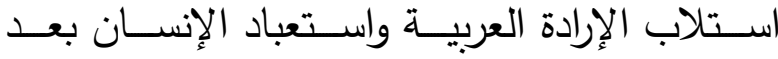

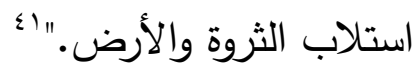

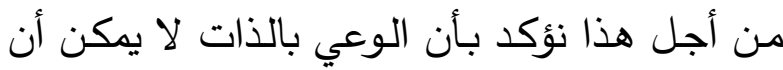

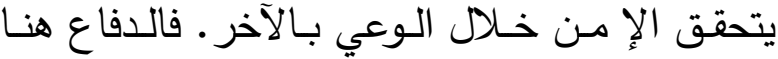
شكلا من أشكال الوعي بالذات وتأكيد الهويـة وفهم

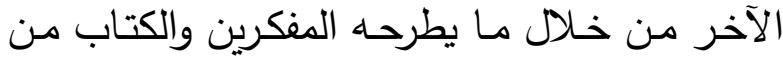
فكر وأدب. فلجوء الكتاب إلى إبراز هوياتهم يوضح

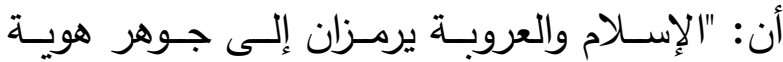
الذات المغاربية، في وعي مثقفي المغرب العربي، وذلك بسـبب مـا اتســت بـه السياسـة الاستعمارية

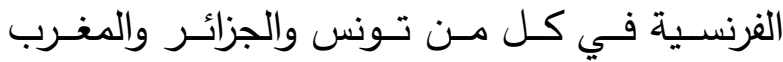

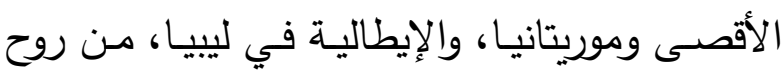

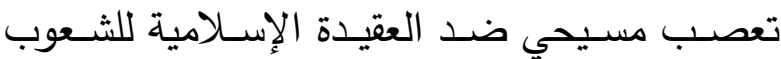

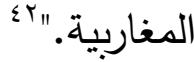
والتحرر مـن الغرب معنـاه التعامل معـه نقديا. أي

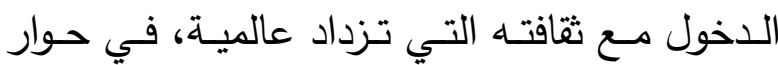

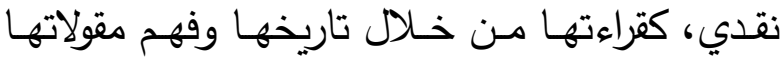

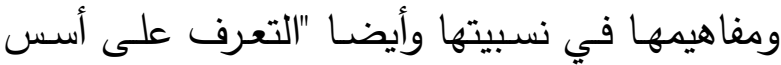
تقدمها، والعمل على استنباته في تربيتنا الثقافيـة.

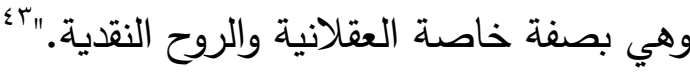

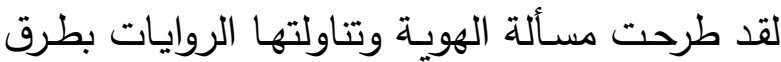
مختلفــة تعكس مـن خلالهـا علاقـة الذات بـالآخر وتبرز إشكاليات متعددة. فإثارة الغرب أو المستعمر

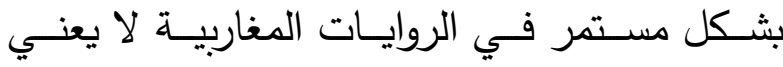

1؛ المرجع السابق ذاته، ص:

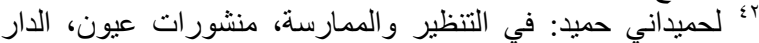

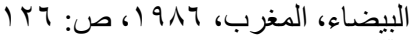

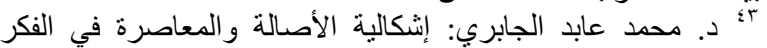

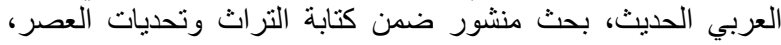

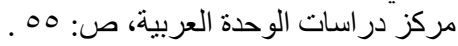

تجـاوز هذين العنصـرين. ومـا يمكن أن نميزه في الرواية المغاربية وبشكل متكرر عند معظم الكتاب ينقسم إلى: - ئى هوية الأنا والآخر : ضياع أو فقدان الهوية:

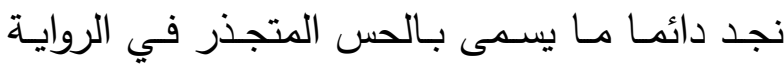

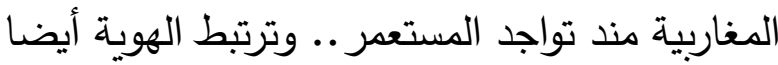

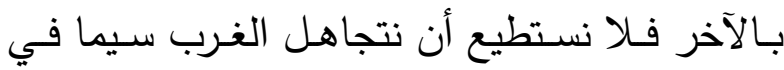
المراحل العصيبة التي مرت بها البلدان المغاربية

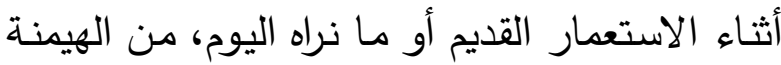

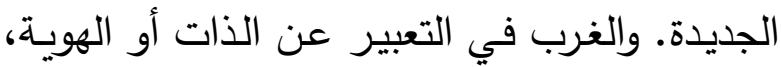
ينقسم إلى غـرب إيجابي وهو الحضـاري والآخر سلبي وهو المستعر • وهناك صدام مع هذا الآخر

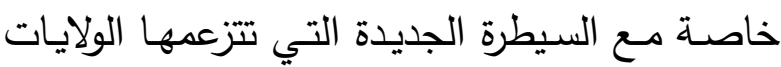

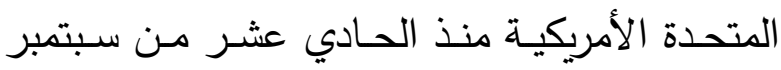

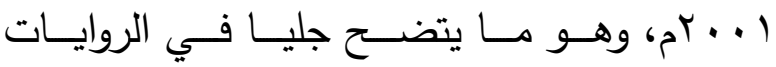
المعاصرة. - أمات أمـا إشكالية الهويـة في الإبـداع المغـاربي المكتوب بلغتين متباينتين فقد انطلقت منذ عهد الاستعمار واستلاب الحقوق بسبب "غياب التكافؤ في العلاقة القائمة بينهما وهذا التكافؤ لا يمكن أن يتحقق قبل

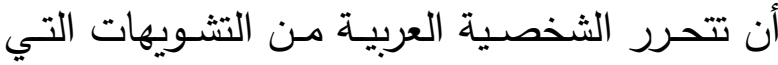

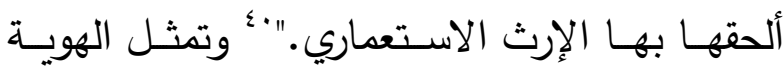
القوميــة والوطنيــة فـي الأدب المغــاربي: "سـلاحا

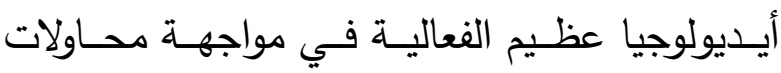
الاختراق الثقافي وتذويب الكيان الحضـاري العربي لوني ضمن أنساق فكرية معينة وأنماط تغربية تسعى إلى الى الى

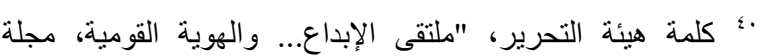

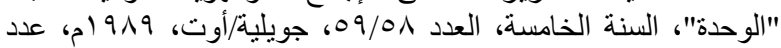
خاص عن "الإبداع والهوية القومية" ص: هـ 
الــوجهين الاســتعماري والحضـــاري الـــيمقراطي التعـدي للغـرب، يمـثلان وجهـين لعملــة واحـدة.

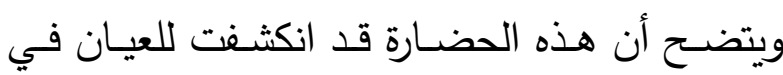
صورتها غير الإنسانية والعدوانية كونها تمثل خطرا

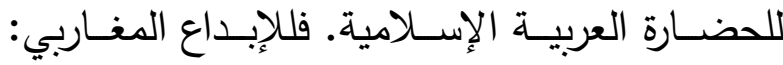
"موقف إدانة عنيف وحاد للغرب يمثل رد فعل على الإنى

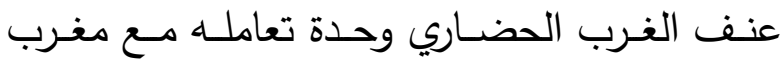

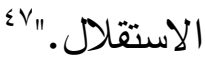

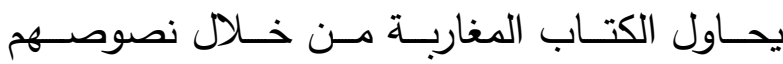

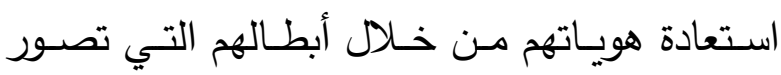
الثرقي أو العربي المسلم في مرآة غربية أو كما يريد أن يراهـا الغربـي في مرآتـه، جغرافيـا وحضـــاريا وسياسيا عبر خرق القوانين والعبور إلى المناطق

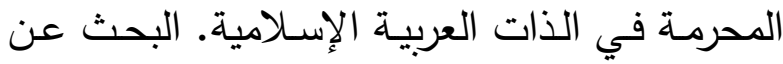

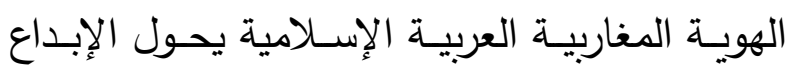

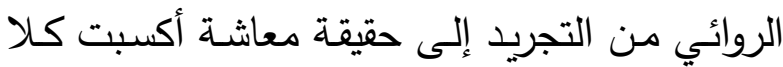

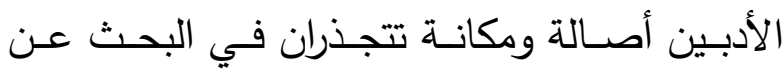

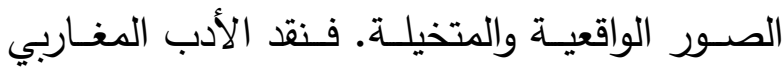

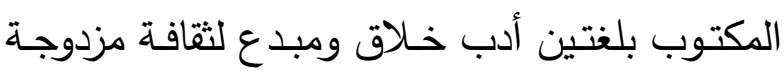
لا تلغي جذورها وإنما تسعى إلى (Culture mixte) تحديثها.

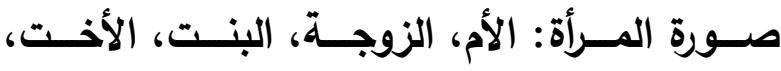
العشيقة والمومس: تحظى المرأة بحضـور فاعل في الروايـة المغاربيـة مما يدل على أهميتها ضمن شواغل الكتاب. وقد بدت المرأة في عدة نماذج من حيث الانتماء والدور حأد. بوشوشة بن جمعة، تجليات أسئلة الهوية في السرد الروائي

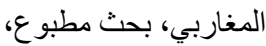

بالضـرورة الخنوع فالقضية قائمسة في صلب الواقع الاجتمـاعي الـوطني طالمـا كانـت هنـاك علاقـات تاريخية وكيان ذاتي. وطرح فكرة الغرب ليست إلا مسألة تعتمد على نوعية التعامل معهد، لهذا يوضح دئح

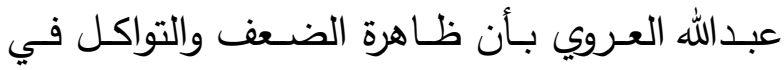
التفكير الأيسديولوجي العربـي ترتبط بإخفـاء أنمـاط

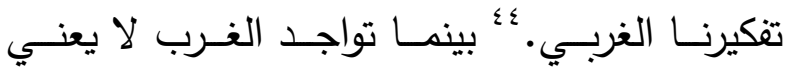

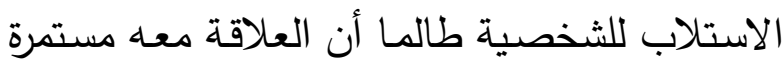
وتحقق مصالح مشتركة. تعدد الرواة والروايات تجعلنا نذهب إلى دراسة الهوية

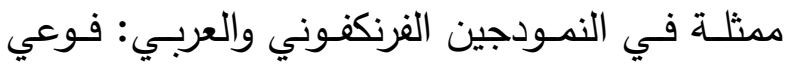

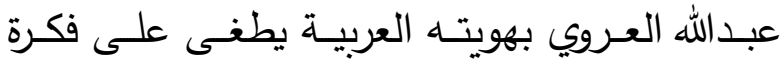
الأديولوجيا أو الإبداعي فهو يتحدث بضمير المتكلم

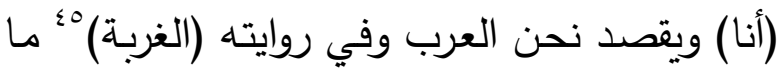
يكشف أمامنا تأصيل ذلك الحس بهويته عبر بطله

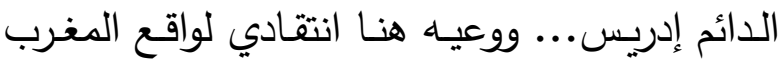

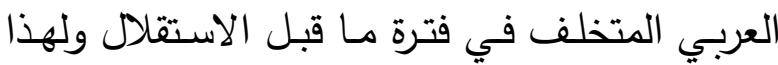

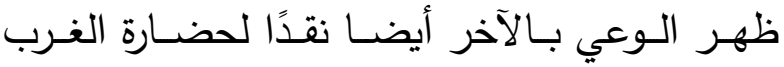
وعامل إرباك لصورته المشوهة. وكذا عند الطاهر

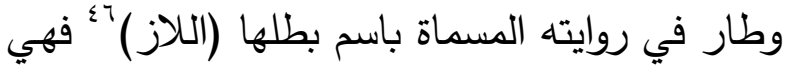

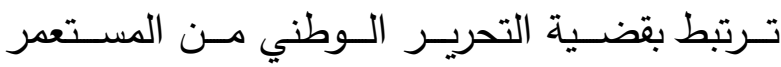

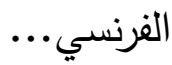
يرسـم الكتاب صـورا بثـعة لهـا الغرب ويكثـفون تهافت حضارتهم وقيمهم المغلوطة سواء في الإبداع

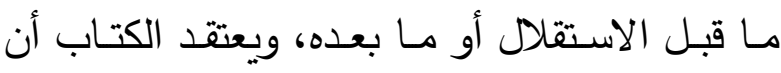

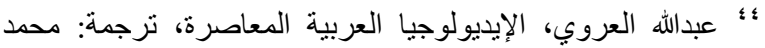

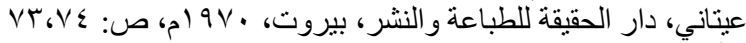

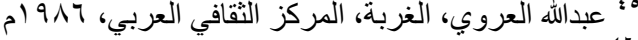

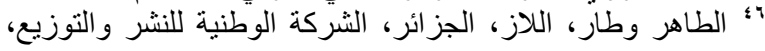


القضايا الاجتماعية: كإدانة وضعها التقليدي وتسلط الفكر الخرافي في كثير من شئون حياتها، فبرز في

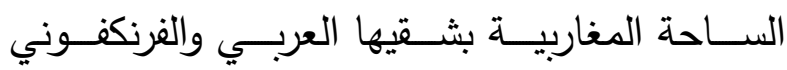
مبدعات أسـهمن في الثورة الإبداعيـة الجماليـة في ليدي بلـدانهن كمـا في المهجـر كآسـيا جبـار أو أحسلام مستغانمي. تسـتطيع المـرأة مـن خـلال ممارســة فعـل الكتابـة الروائية كما يقول بوشوشة: "تكريس مقومات هويتها أنثى بتبني قضـايا المرأة وتقديم البدائل الممكنة لها قصــد تحسـين وضــع المـرأة المغاربيــة." وللمـرأة العربيـة المثقفـة عامـة وفي المغرب العربـي خاصـة دور فاعل في الوعي الاجتماعي الذي نعيشـه اليوم،

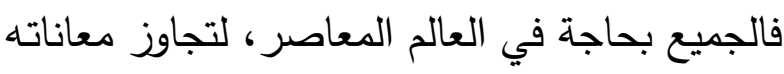
المحلية وفتح ثغور تتواكب مع ما يحيط بمجتمعاتنا. يؤكد رشيد بوجدرة بأنـه: "واع أن الطاقات الموجودة لاى المرأة العربية سوف تتفجر يوما وإذا ما انفجرت فسـوف يـربح المجتمـع العربـي نصـفه المفقود، إلى يومنا هذا وسوف تكون الصورة النسائية التي سينتفع بها الرجل قبل غيره." اه

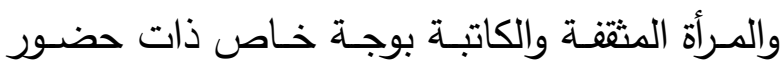
فاعل في الرواية المغاربية، وكمجتمع أقلية، عاشت

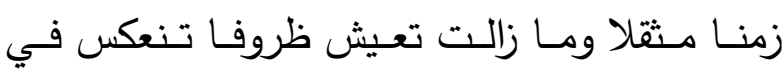
رؤيتهـا للأشـياء وتصـورها لهـا وللمجتمـع المحـيط

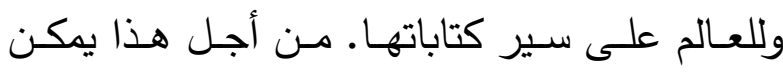

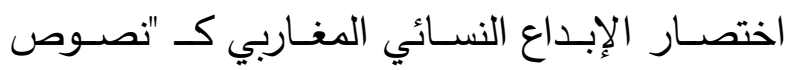

•0 د. بوشوشة بن جمعة، الرواية النسائية المغاربية، نفس المرجع

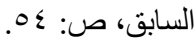

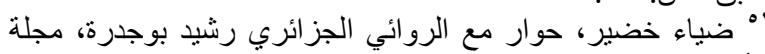

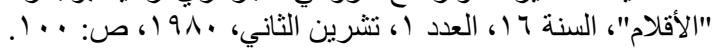

الاجتمــاعي التقليـدي الخرافـي البسـيط أو الفاعـل المعاصر : كالمتعلمة والمثقفة والسياسية.... لقد قسم

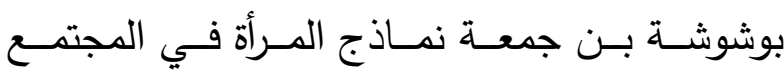

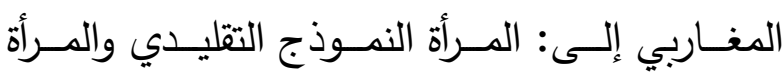
المناضــلة والمـرأة الطـالق والمـرأة المثقفــة ثم المـرأة

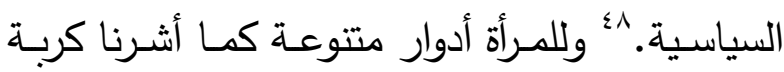
البيـت والزوجـة المطيعـة والمطلقـة والأرمـل والعزبـاء ولكل واحدة منهن دورها ومعاناتها.

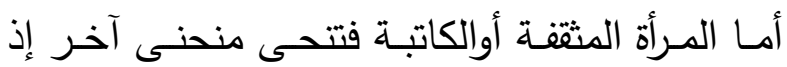
تتصارع مع مجتمع ذكوري يسعى دوما إلى إقصائها

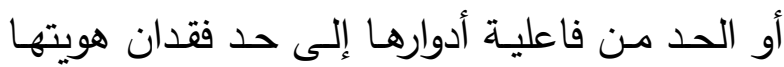
9q (Identité confisquée) في المغرب العربي أثناء مرحلة الاستعمار في أن

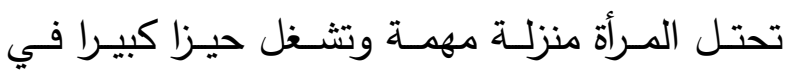
المجال الروائي المغاربي. فعندما نعبر عن الكتاب فـي المغـرب العربـي فإنـــا نشـير إلـى المبـدعين والمبدعات معـا. أفرز الوضـع الثقافي في المجتمع المغـاربي، جيلا مـن الكاتبـات ذات التعبير العربي والفرنسي وأثَّر في ممارستهن الإبداعية التي مكنتهن مـن التعليم والعمـل والسـر والترحسال والخوض في

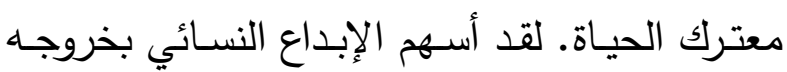
مـن الهيمنــة والاسـتلاب وتجـاوز العوائـق والقيـود

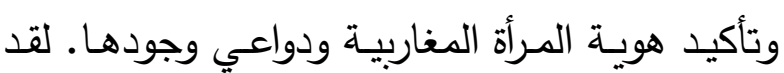

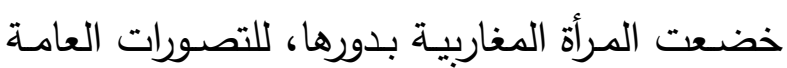
وللمواقف والرؤى التي خصصها المبدعين لمختلف

^؛ د. بوشوشة بن جمعة، الرواية النسائية المغاربية، المغاربية للنشر،

49 Arlette Chemain, Emancipation féminine et roman africain, Les nouvelle éditions africaines, Dakar, Abidjan, Lomé, 1980.P.55 
لا يحملن. 0. وكتب كذلك عن نفاق الرجال الذين يمارسـون مـع التلاميـذ ونسـاء يـبـن أنفسـهن في الطرقات به وكتب عن مشكلة الزنا بالمحارم كزوجة الأب التي وصـف فيها بوجدرة حالـة البطل وهـو يصف جمال زوجـة والده بعد أن يستمتع أبيـه بهـا

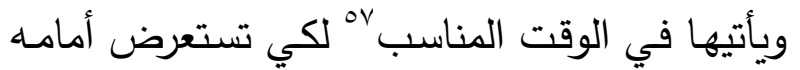
ولكي يعاشرها ويستمتع بها في زينتها وهي تأتي إليه في الوقت المناسـب معطرة. ^ه ثم يفرق بين زبيدة كامرأة أخرى غير أمه الصامتة، فزبيدة متحررة ومن جيل مختلف ولم تعد فقط للجنس كما كانت أمه. تشكل الخطاب الروائي:

يتشـكل الخطـاب بتشكل الروايـة داخـل المـتن كمـا يتشـكل حـول إسـهام الروايـة وتشكيل بنيتهـا وبنيـة أشخاصـها، ويوظف الخطـاب الروائي العديـد مـن الصـفات التي تتميزز بهـا سـيما الكتابـة التاريخيـة. وينقسم هذا الإبداع بين خطاب غائب وآخر حاضر • ويتطرق الخطاب الروائي المغاربي، في مجمله، إلى ثلاثة عناصر رئيسة هي:

اــ الـديني: الإسـلام والمسـيحية واليهوديـة: تعد الخطابـات الدينيـة مـن أهم الخطابات التي حظيـ بأهمية قصوى في كثير من الروايات التي كتبت في الأدب المغـاربي وصـنعت دلالاتهـ مـن حيث البنيـة والوظيفـة. تتتاولـه الروايـات غالبـا، باحترام وتمجيد. يحرك هذا الخطاب وجدان الشخصية وتواصلها مع

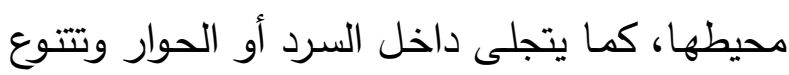

\footnotetext{
${ }^{55}$ Rashid Boudjedra, Op/cit, P.66

${ }^{56}$ Rashid Boudjedra, Op/cit, P.95

${ }^{57}$ Rashid Boudjedra, Op/cit, P.67

${ }^{58}$ Rashid Boudjedra, Op/cit, P.116
}

مشـحونة بالاحتجـاج والـرفض لوضـع المـرأة العربيـة المختلف في مجتمعات تكرس سلطة الرجل وتستلب

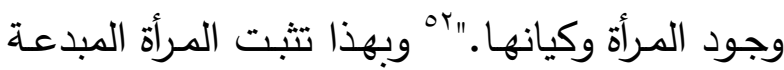
وجودها وتعزز استقلالها وتبرهن على ما تملكه من قدرات من خـلال بـث همومها ورفض السلطة أيـا كانت والبحث عن إبراز تجربتها وممارسـة حربتها وإقامـة علاقـة جماليـة مـع الواقـع ومحاولـة معالجـة قضاياها الذاتية وقضايا مجتمعها المعاصر • أمـا القضـايا النسـائية المثارة في الروايات المغاربية فقـــ جعلـت النسـاء مـرآة عاكسـة لمـا تعانيـهـ المـرأة المغاربية، فهي حارسـة المنزل وهي المحافظة على التراث وهـي الصـمت المطبـق وهـي الســن وهـي القـلق وهـي الرغبــة الجنسـية وهـي الثــهوة وهـي

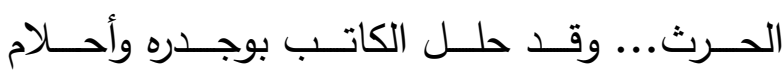
مستغانمي تلك المـرأة في روايـاتهح ووصففوا معانـاة المرأة وما تعانيه من شعور بالعار وما ينطبق عليها مـن العيـوب الاجتماعيـة كمـا تقـول أرلـت شـمان (Arlette Chemain) سبيل المثال في مواضيع جنسية أخرى كالمومس... وتحدث بوجدرة عـن نفس المشـكلة وأوضـح بـأن الرجال يسموا زوجاتهم بأسماء مومسات به وحالة ما وات (الأم وهـي تمـارس (Ma) masturbation)

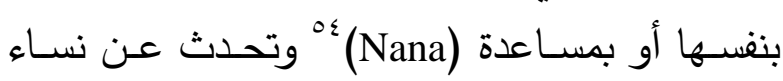
أرامل يفضلن ممارسة ذلك مع الأولاد الصغار لكي

\footnotetext{
ها د. د. بوشوشة بن جمعة، الرواية النسائية المغاربية، سبق ذكره، ص:

${ }^{53}$ Rashid Boudjedra, La Répudiation, Gallimard Folio, 1981, P.39

${ }^{54}$ Rashid Boudjedra, Op/cit, P.93
} 
النصـوص.. عنف متخيل سياسـي يجد تعليلـه في ممارسـات سلطة الاستقلال التي يكاد يجمـع كتاب هذه الروايـة مـن جيل السبعينات والثمانينـات على أنها تشكل نوعا من الامتداد لسلطة الاستعمار • يتم حضور هذا الخطاب من خلال الشخصيات وإبراز

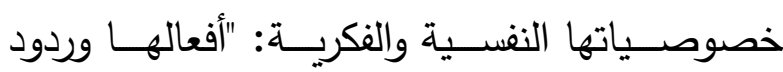

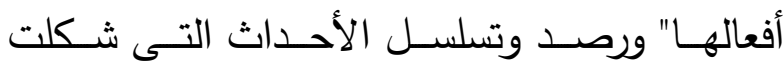
السياسة. rـ التاريخي: هذا الخطاب ينقلنا إلى الأحداث من خـلال إشـارات ووقائع في فترة زمنيـة مـا يمكن أن نحـد بعـدها مكانتـا وزماننـا ويـرتبط هـذا الخطـاب بالخطـابين الســابقين.. يـتم التعامـل مــع الكتابــهـ المغاربيـة على نـوعين مـن التـاريخ يتـداخلان في في

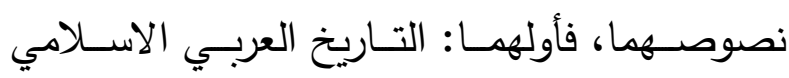
قديما، وثانيهما: التاريخ الحديث والعرب والمسلمين عامة والبلدان المغاربية خاصة. ع - الجنس: يندرج الجنس في روايات وعالم المغرب العربي، ضمن المحظورات الدينية والمجتمعية والضوابط الأخلاقية والمسائل المحرمة شرعا وعرفا. وعالم الثهوات في المتخيل العربي، ممارسة غير شريفة وهي عبارة عن مكابدة للههوم الذاتية وتجربة رحلة وضياع في عالم متسكع. ما هي هذه الظواهر ، وكيف يتعامل الكاتب المغاربي مع هذه الظاهرة ؟! لا شك أن هذه الظواهر تتعدد في الروايات المغاربية وتتحدث عنها وتتمثل غالبا في المصطلحات الفرنسية التالية: La sexualité bafouée: la

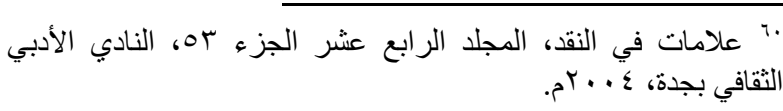

أشكال الخطابـات بين الشخصيات؛ إذ نجدها بين محافظ يرى في الدين كتابا ومنهاجا يجب الاحتذاء بـه فهو صـالح لكل زمـان ومكان، وبين آخر ينفر من الدين ويعتقد أنـه قد فقد مصداقيته وتأثيره على النفوس، فهو جيـل يبحث عن الحريـة. مثال ذلك بطلة رواية رشيد أبو جدرة في (يوميات امرأة آرق)، عندما تتضـر منزعجة من الأذان عند كل صـلاة فجر r. السياسي: يتصدر إشكاليات الرواية في المغرب

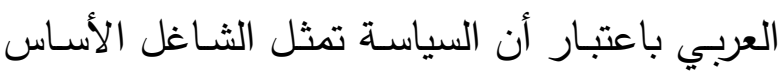
للكاتـب المغــاربي بسـبب انعكاسـاتها علـى واقعـهـ الـذاتي والمجتمعسي وهـي انعكاسـات سـلبية فـي الأغلـب، يقـول الطـاهر وطــار : "السياسـة... هـي الصدى الوحيد لهمومنا الباطنية والعلنية... هي هم

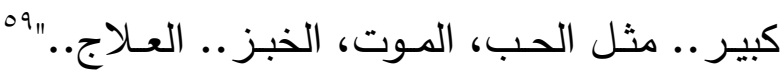
يختفـي الخطـاب السياسـي غالبـا، خلـف الخطـاب الديني ليحقق مبتغاه من خلال استغلال إمكانياته: أما الشخصيات فيه فتنقسم إلى قسمين: شخصيات القسم الأول لا تدرك مـا تقول ولا تفهم إلا القشـور وشخصـيات القسـم الآخـر واعيـة وعلى قـدر مـن

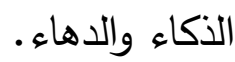
تطـرح الروايـات المغاربيـة قضـايا سياسـية يختلفـ وماء عمقها وإدراكها للواقع من كاتب لآخر إلا أن طرحها ينقسم بين المباشر والضـمني. وتتميز بجرأتها في ملامسـة القضـايا والتعبيـر عن الموقف منهـا وهذه الجرأة إلى حد السب والشتيمة واللعن في كثير من

9ه الحبيب السائح، زمن النمرود، المؤسسة الوطنية للكتاب، الجزائر، 
بفنـون مـن التلمـيح وأمسكن عـن تسـية الأشـياء

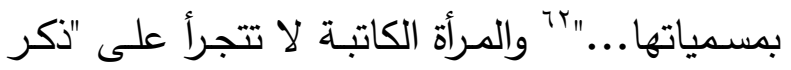

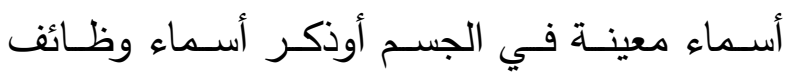

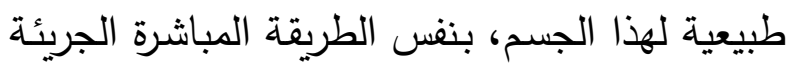

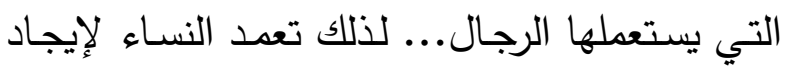
كلمات أو عبارات مهذبة وملطفة قد تصبح مع كثرة

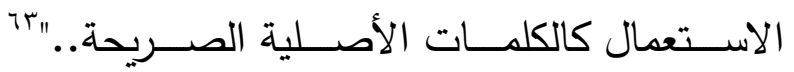

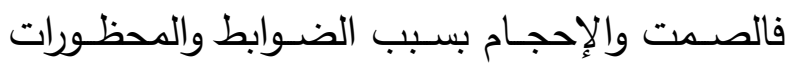

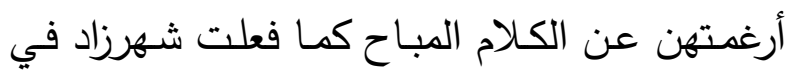
الف ليلة وليلة. والمرأة فوق كونها موضوع لإرضاء رغبات الجنس

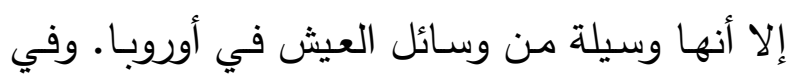

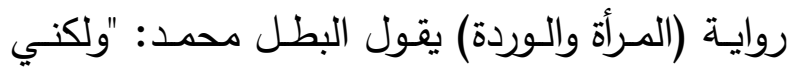

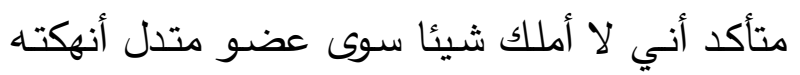

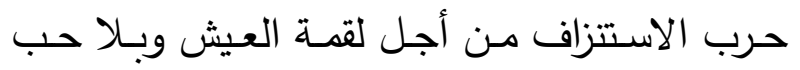
مثل عاهرة سأمشي وسأوزع البسمات، أقول للعالم

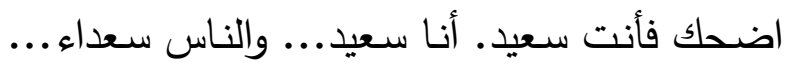
وحتى إذا لم أكن سعيدا فسأتخيل ذلك أوأفتعله."

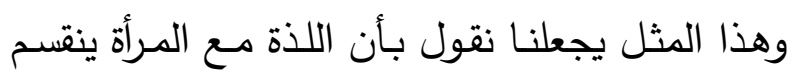
إلى: إما أن يكون دنسا وغريزة تبحث الخلاص منها أو أن المرأة تتحول كوردة نتوق إلى شمها وحضنها.

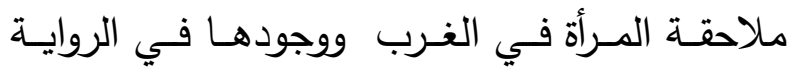

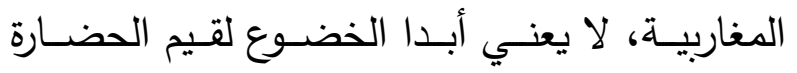

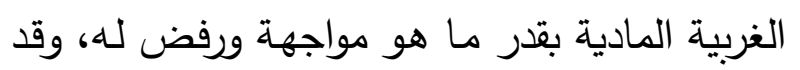

هי" د. بوشوشة بن جمعة، الرواية النسائية المغاربية، سبق ذكره، ص:

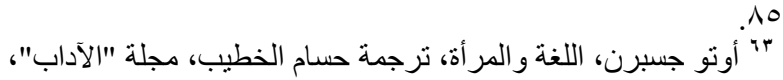

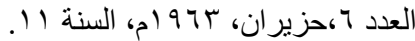

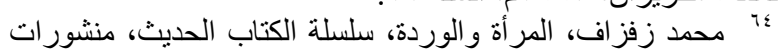

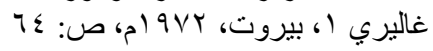

mutilation sexuelle, la prostitution, (l'homosexualité, l'inceste (Les lesbiennes) (Les Sadomaso) L’androgyne: ) الخنثى: نصف أنثى ونصف رجل ث (un être double: mi-homme, mi-femme الرجل الرجل (Homosexualité masculine). تحدد هذه الظواهر التي تبرز في الروايات المغاربية في الأغلب على خلفيـات النشـأة والثقافـة ومفهـوم

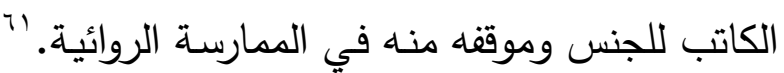
فـالمعلوم لـدى الجميـع أن البيئة المحافظـة والثقافـة التقليديـة يبلوران في الأغلب موقفا محافظلا يتهيب مـن أحكـام البيـــة وضــوابط الأعـراف الاجتماعيــة والدينيـة. فيعـرض لموضـوع الجنس بشـكل محتثـم لأنـه من الموضـوعات المحرمـة في الذهنيـة العربية

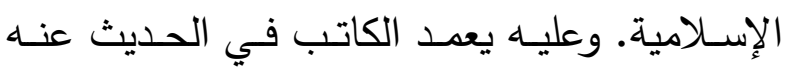
باستخدام أفانين الكلام من مجاز واستعارة وتثبيه: فنـون بلاغيـة تسـهم مجتمعـة لتشـكيل رمـوز شـفافة ودالة عن المسكوت عنها. يلجأ الكاتب لذلك مخافة ارتكاب المحظور وتجاوز المسموح بـه من الكـلام. الا أن ذلـك لـم يحـل دون وجـود بعـض التجـارب الروائية ذات التعبير العربي والفرنكفوني التي تميزت بجرأتها في طرح هذا الموضـوع كرشيد بوجدرة في الجزائر ومحمد شكري في المغرب الأقصى.. نستطيع أن نؤكد في الموضوع ذاته، بأن الكاتبات في الروايـة المغاربيـة قـ طـرقن لموضـوع "الجســـ والجنس بنوع من الحرج فتحدثن عنه ـ في الأغلب .

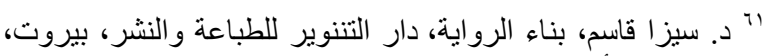

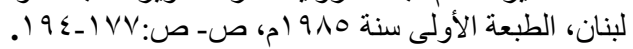


- V الأنمــاط الروائيــة: تتعـدد الأنمــاط الروائيـة وتختلف باختلاف تراكيبها وصيغها، ومن أنماطها:

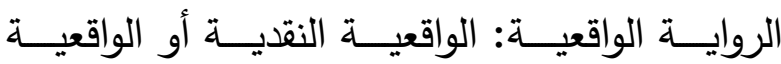
الاشتراكية والعديد من الأنماط، كما تضم الروايات المغاربية مقاربات ودراسات إلى جانب شهادات تعيد

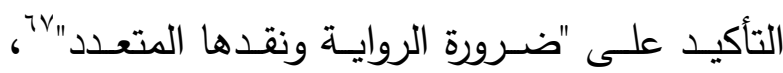

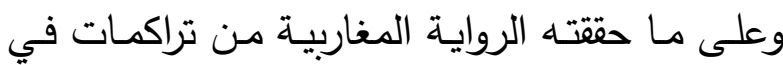
فضاء المشهد الإبداعي. والعديد من الدراسات تثبت مدى ما تمثله الرواية في المغرب العربي ومدى ما الإليا

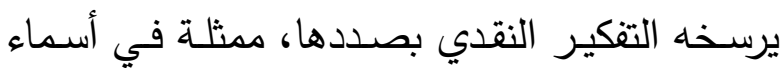

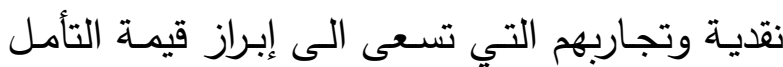

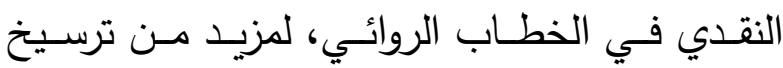

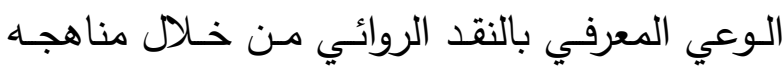
وتصوراته ومفاهيمه.

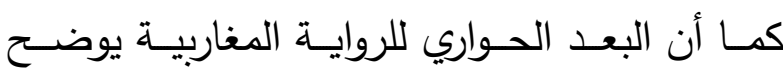

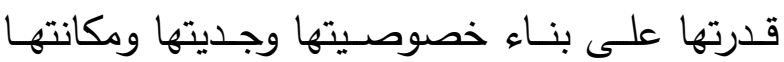
يسـاعد في صـياغة تصـورها الإبـداعي وهاجسها

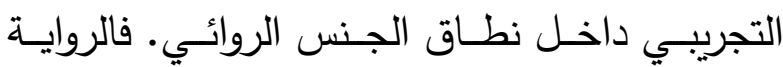

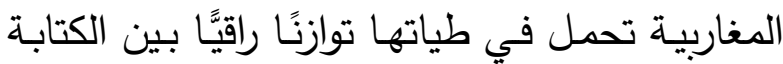

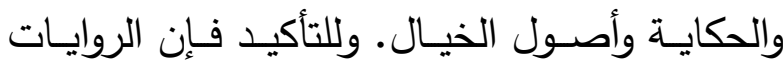
المغاربية تسير نحو خلق توازن بين مختلف وظائفها الجمالية والمعرفية والتداولية التي تتجلى في مختلف لورن بلفين أرجاء المغرب العربي والعالمي.

VT تداخل الثقافات والكتابات الأدبية، فعاليات الملتقى المنتظم بقصر

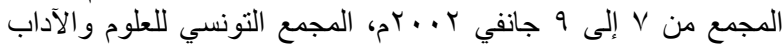

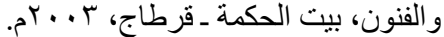

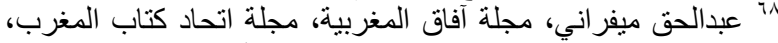

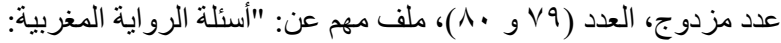

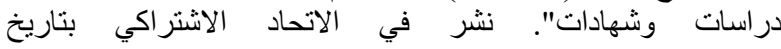
إن
تعني اللذة مـع المـرأة الغربيـة في الأدب المغـاربي:

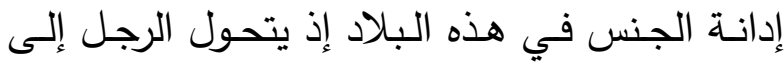

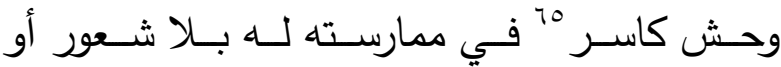

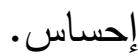
ه- الأيسيولوجيا: حضور الأيديولوجيا صسارخ في

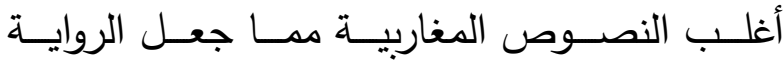

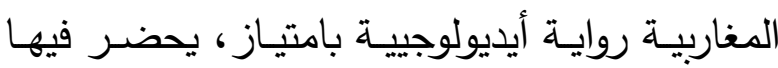

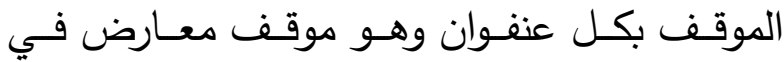

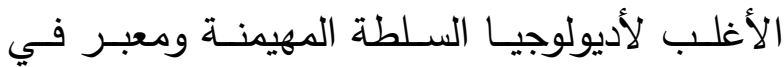
الوقت نفسـه عن أيديولوجيات كتاب هذه الروايـة.

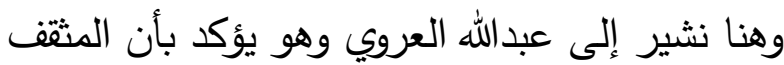

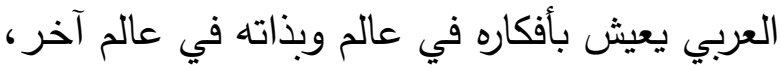

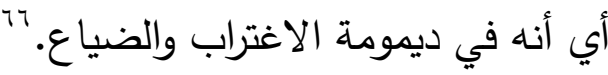

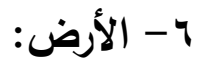
الحنين للوطن (La nostalgie) ويحملها كلٌّ منا في

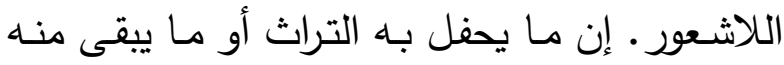
هو الوجه الأصيل الذي يتجلى في الحياة الإنسانية:

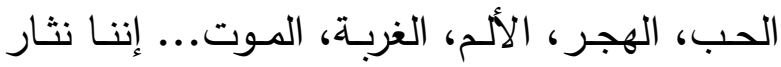

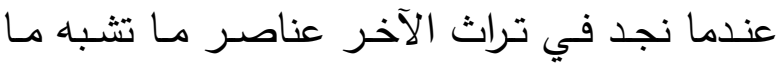

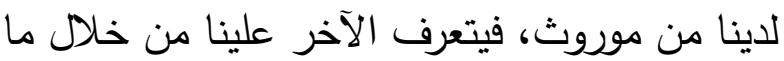

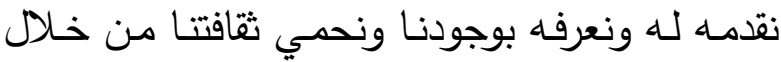

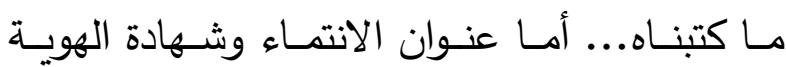

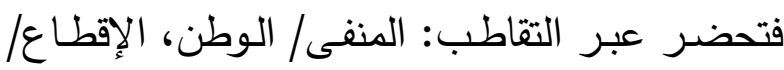
وصغار الفلاحين... - (

\footnotetext{
${ }^{65}$ Sigmund Freud, Totem et tabou: une interprétation par la psychanalyse de la vie sociale des peuples primitifs, éd. petite Bibliothèque, Payot, 1979.

"r عبدالله العروي، الإيديولوجيا العربية المعاصرة، ترجمة: محمد

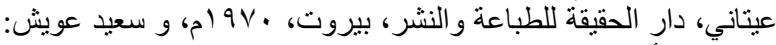

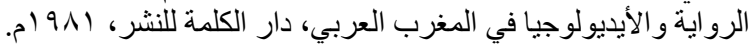


مجملـه على الخيـال القـائم على بعض الكثـوفات العلميـة. والنصـوص الروائيـة مـن هذا الطرح قليلـة جـدا. ومنهـا: (الطوفـان الأزرق $9 \vee 7$ I ): لأحمـد عبد السـلام البقالي و(أكسير الحياة 9 و ( ) لمحمد العزيز الحبابي في السنة ذاتها في المغرب الأقصى

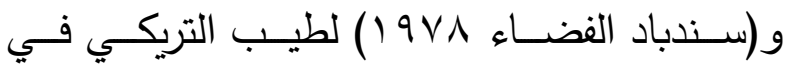
تونس. "V وجميعها نمط حاول فيه بعض الكتاب أن يحـاكوا نصوصــه الغربيـة ولكنـه سـرعان مـا تلاشـى لفتـور تقبـل القـارئ المغربـي والعربـي لمثـل هـذه

الأنماط.

د - روايـة التأصسيل أو التـراث: الأصسالة والحداثـة: يعـد حضـور الماضــي في الثقافـة المعاصـرة بعثا للنزعـة التأصـيلية فـي بعـض الروايـات المغاربيـة المدونــة بـاللغتين الفرنسـية والعربيــة. فهنـاك مـن الكتاب من عاد إلى التراث واستثر شخصيات ذات قيمـة تاريخيـة لينـي عليها روايته كمـا فعل الكاتب المغربي إدريس شرايبي في روايته: ('Homme du Livre ). والكاتب التونسي محمود المسعدي في روايـة: (حدث أبو هريـرة قـال... التراث مكنـت هاتان الشخصيتان مـن الغوص في

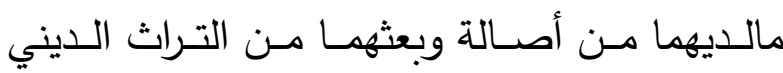
والحضـاري الإســلامي ليصـال إلى فكـرة المعاصـرة والعراقـة ؛ فجســا مـن هـاتين الشخصـيتين الـذات العربيـة فـي عصسريهما المتجــاذبين بـين قطبـين

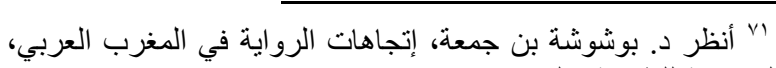

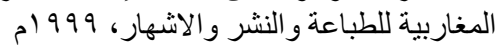

72 Driss, Chraïbi, L'Homme du Livre, éd. Balland-Eddif., 1995, p. 94.

rr محمود المسعدي، حدث أبو هريرة قال، الدار التونسية للنشر، تونس، .94 6) $9 \vee r$
تبـرز أصــوات الروايــة المغاربيــة الجديـدة مؤشـرًا للتحـول في وعي المرحلـة الحديثـة فنيـا وجماليـا. فهنالك ثراء تخييلي وتعبيري واهتمام متزايد باستعادة فن الحكاية مما يجعلها نصوصا مفتوحة على العالم وعلى مواكبة تحولاته. كمـا تعدل الرواية المغاربية

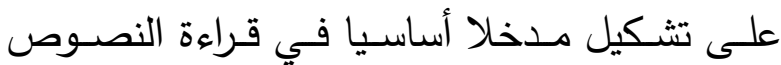

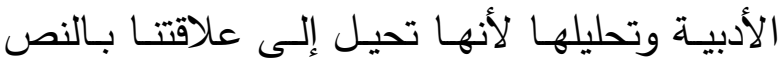

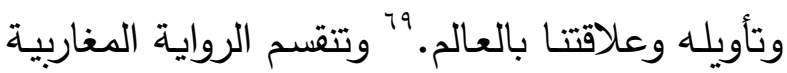
إلى أ- الرواية التاريخية: نقصد بها تكميل التاريخ في بعـض جوانبـهـ وأحداثـه. فتــــل معظـم الحقــائق التاريخيـة لإلبـاس الروايـة ثـوب الحقيقـة وذلك مـن

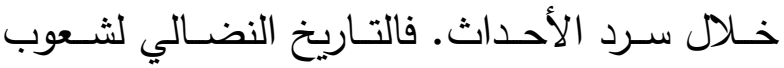

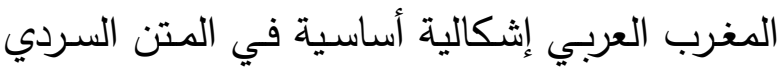
الروائي ولمختلف المواقف. ب - روايـة السيرة الذاتيـة: تسيطر ضمائر المتكلم

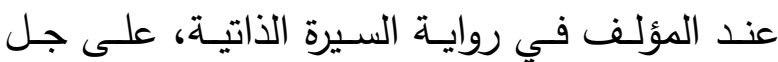
أعماله السردية. كما نجد أن عنصر (الأنا) يسيطر

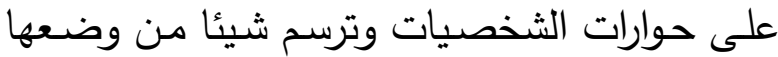
الاجتمــاعي والنفسـي وتتمحسـور مـا بـين الـذاتي والموضوعي والواقعي والمتخيل. v. v ج- روايـة الخيـال العلمي (Science fiction): تعمق هذا النوع خاصة بعد النصف الأول من القرن العشرين ويركز على محاولة كثف أسرار المستقبل العلميـة والفضـاءات الكونيـة. ينبنـي هذا الأدب في في لعني (97 مجلة آفاق المغربية، مجلة اتحاد كتاب المغرب، عدد مزدوج، العدد المداب

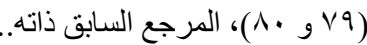

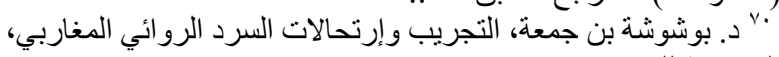

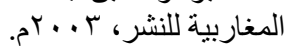


وفي الروايـة المغاربية، وظف التراث ضـن مذهب تحديثي في الكتابـة الروائيـة عبر استرجاع النص

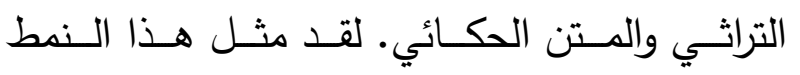
التأصيلي عدد كبير من الكتاب المغاربـة وبـاللغتين الفرنسـية والعربيـة كـإدريس شـراييبي والطـاهر بـن جلون وبو جدرة وأحلام مستغانمي وواسيني الأعرج وغيرهم الكثير • العودة للتراث كما يوضـح الكيلاني: "لـيس نصوصـا جامـدة تحفـظ في أمهـات الكتب ئب القديمـة، بـل هو الفكر الحاضـر يعيد الحيـاة للنص التراثي ويزرع فيه روحا جديدة."

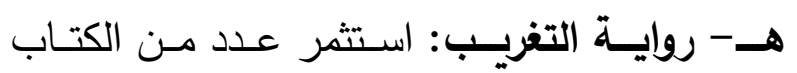
منجزات الروايـة الغربيـة واستندوا في ذلك إلى أن: "الروايـة فن غربـي بحت. بأصـوله... وبقيمـه الفنيـة ومعـاييره الموضـوعية التي رســها لـه كبـار النقـاد

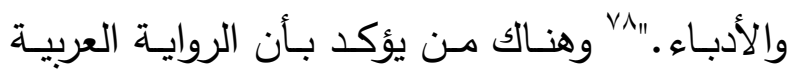

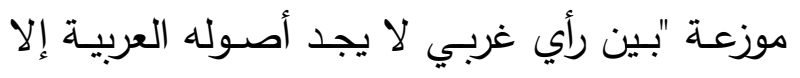
في الغرب، ورأي آخر منـاقض لا يـرى في الروايـة

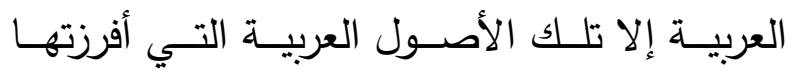

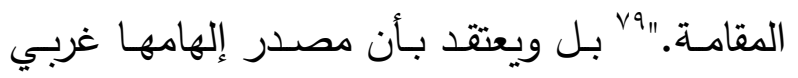
بحت. يلجأ بعض الكتاب إلى اتخاذ الرواية الغربية

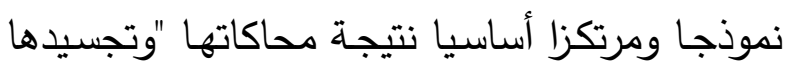
روح المعاصـرة، وبـأن الحداثة الروائيـة لا يمكن أن تتحقـق إلا مـن خـلال منجـزات الغـرب الروائيـة،

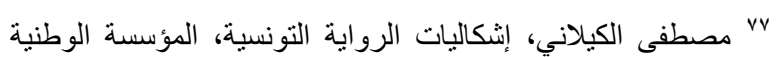

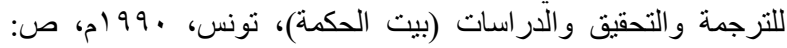

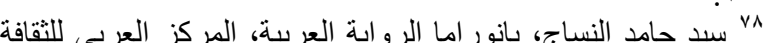

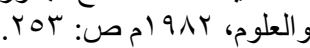

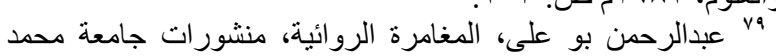

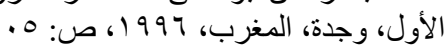

متـافرين وبين حضـارتين وثتافتين ليستا مختلفتين فحسـب بـل متتاقضـتين. يكشـف هـذا الطـرح عـن حداثة الكتابة لدى الكاتبين اللذين يؤمنان بضرورة

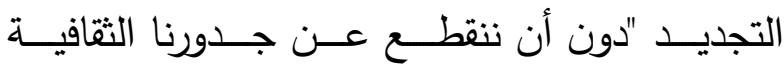

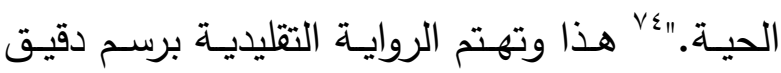
للشخصية وحبك لحكاية ممتعـة بينمـا تعتمد الروايـة الحديثة على اللاشعور والأصوات الخفية في أعماق الإنســان. تمكـن الكاتبــان مــن اســتثمار هــاتين الشخصيتين ومنحاهما صفات عصرية تتعايش مـع جوهريهــا وحقيقتيهما...ولهـذا حساولا تأصسيل فكرة الهويــة الثقافيـة والحضــاريـة فـي بعـدها العربـي والإسلامي لتتمكن من مواكبة عصرها الجديد. تتخلص الرواية المغاربية المتأصلة والمكتوبـة بلغتين والتي تستتد إلى التراث العربي الإسـلامي، من قيود الروايـة الغربية كرواية جمال الغيطاني عندما كتب "الزينـي بركات" عربي أصيل حاول من خلاله: "التعبير عن قضايا الواقـع الجغرافـي وتحقيـق قـدر أكبـر مـن حريــة

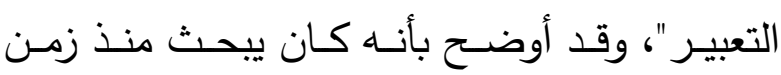
"بضرورة خلق أشكال فنية للرواية، تستمد عناصرها من التراث العربي..." نزعــة تجاوزيــة وحداثيـة لإثبـات الهويــة الثقافيـة والحضاريـة.

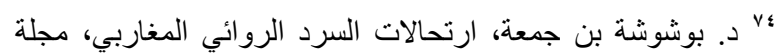

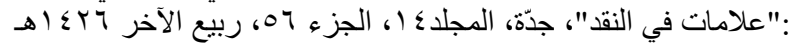

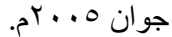

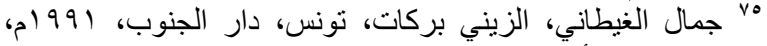

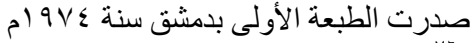

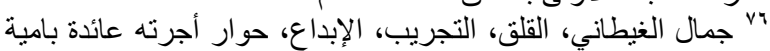

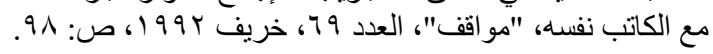


بـالأحرى ذاكـرات: الــذات، المجتـــع، التــاريخ،

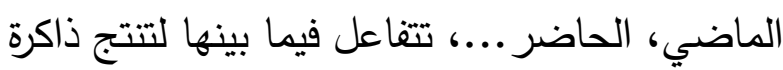

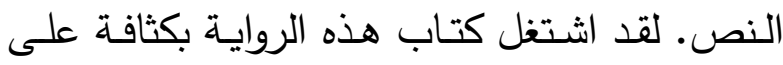

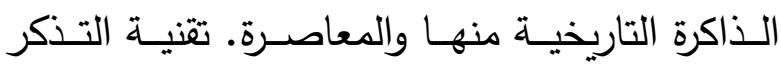
مكنت كتاب الرواية من اختراق النسق الكلاسيكي

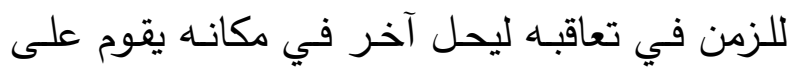

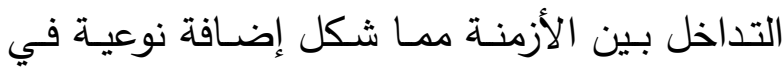
تشكيل الخطاب الروائي المغاربي. التداعي

تتداعى الأفكار والمواقف في الروايـة المغاربية في نصيها العربي والفرنسي وتتوالى كما يقول الروائي

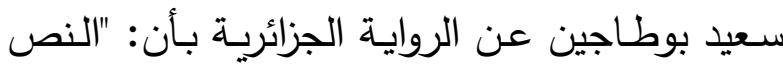

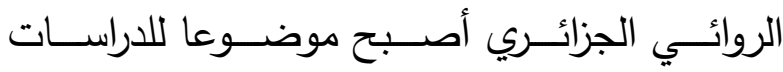

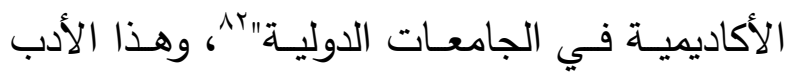
جزء لا يتجزأ من الأدب المغاربي، ويتطرق الكاتب

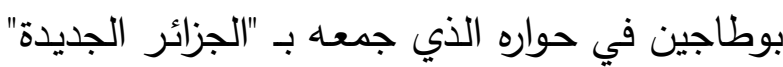

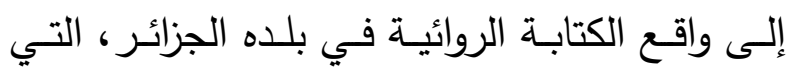

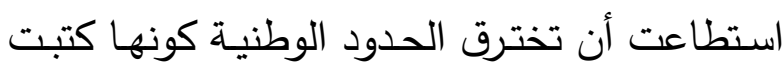

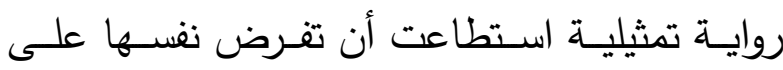

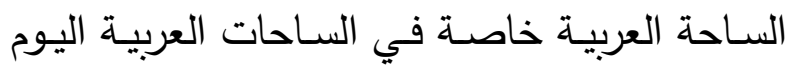

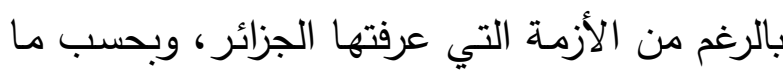

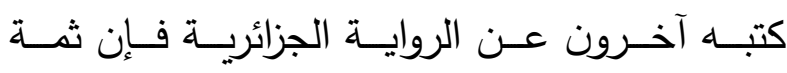

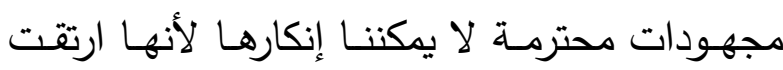

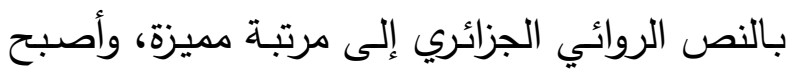

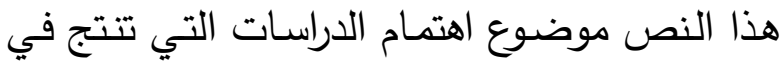

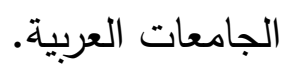

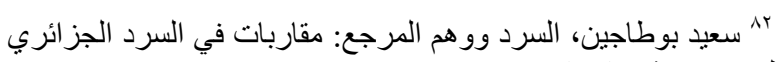

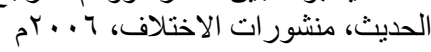

لافتقـار المـوروث السـردي العربـي السـمات الكفيلـة

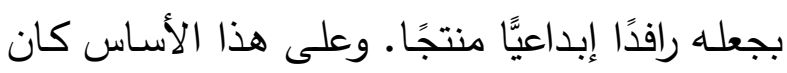

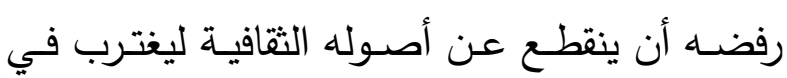

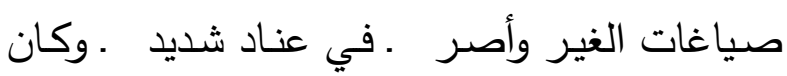

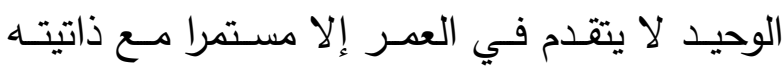

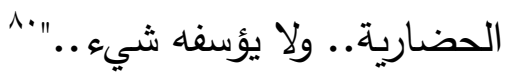

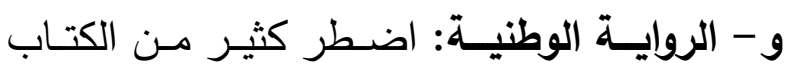

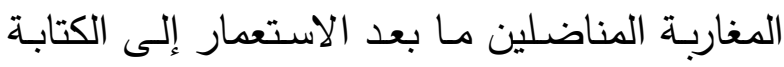

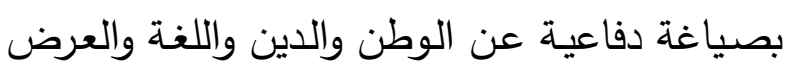

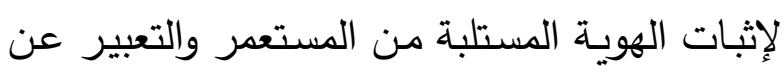

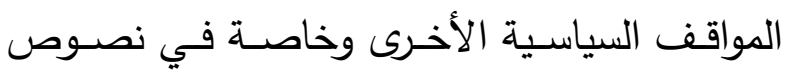

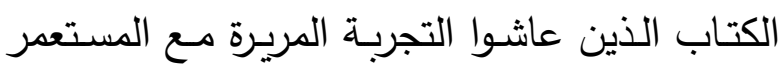
أمثال محمد ديب وكاتب ياسين ومولد فرعون...

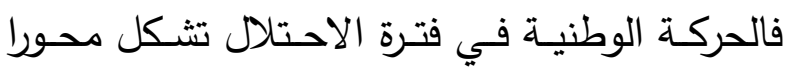

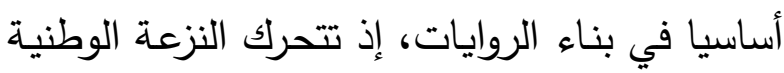

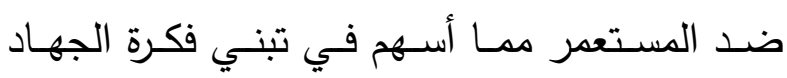
بالمال والنفس والكلمة. لم ينطلق الوعي لدى الكتاب تئس

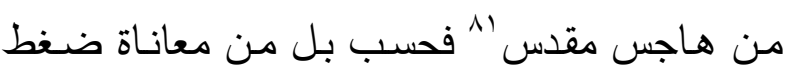

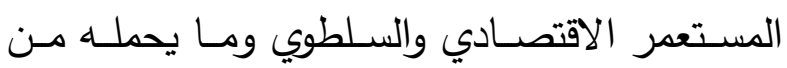
تهديد للحريات والمصالح التقليدية وشل حركة أهل البلاد.

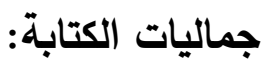

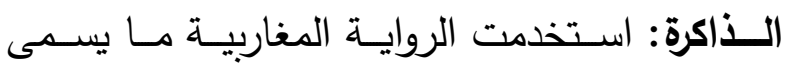

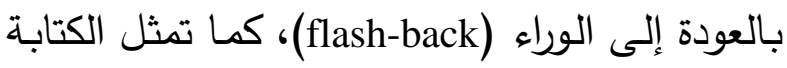

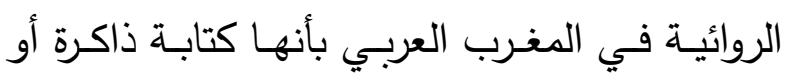
•^ د. بوشوشة بن جمعة، ارتحالات السرد الروائي المغاربي، مرجع سيق ذكره.

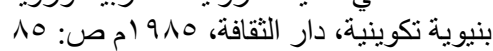


r.التأثر بالرواية الفرنسية الجديدة عند (كلود سيمون (Claude Simon)، وميشيل بوتور بانه Alain (Michel Butor) (Robbe-Grillet (Jean Ricardou) الرواية المنولوجية عند جيمس جويس ( James Joyce)، وفيرجينيا وولف (Virginia Woolf)، وهنغواي Miller Hemingway) (Ernest ودوس باسوس (DosPassos)، وكافكا (Kafka)، ومارسيل بروست (Marcel Proust)... r.الاطلاع على النصوص الروائية العربية الجديدة

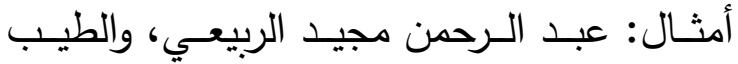

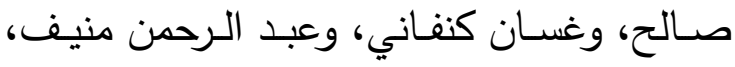
وغالب هلسا، وحيدر حيدر ...

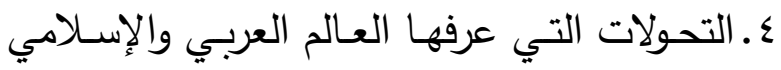

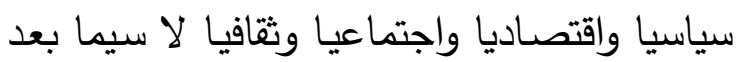

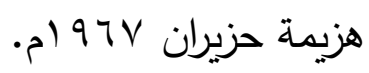
ه.بروز فكرة التمـرد على الأنمـاط والقوالب الفنيـة

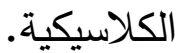

وعليـه، نـوَّع الروائيــون المغاربــة الجـدـد مواضـيع

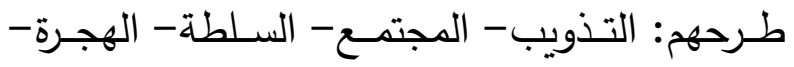

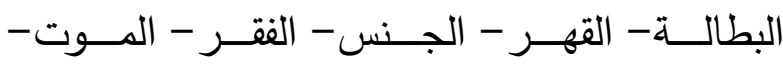
الإخفاق - الغربـة- الثطارة- العبث...، كما نوَّعوا

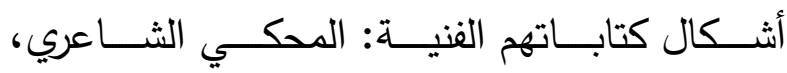

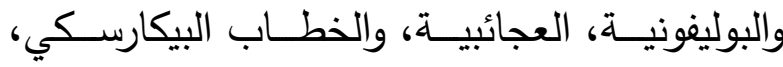

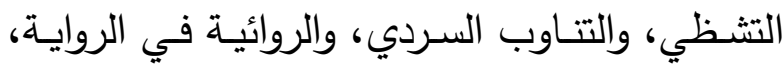
والسرد الرمزي والأسطوري...
تيـار الـوعي: الـوعي بالذات وكيفيـة التعامـل مـع

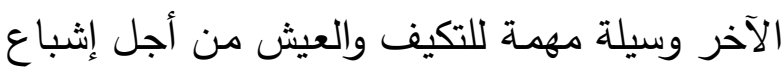

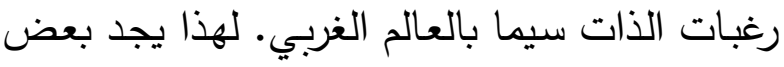
أبطال الروايات بالغرب مصدرا لحل مشاكلهم الذاتية

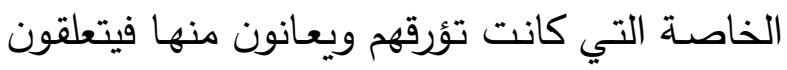

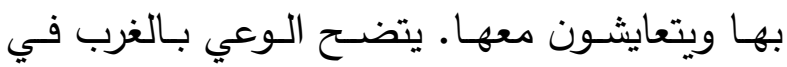

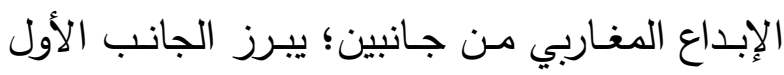

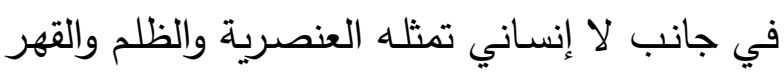

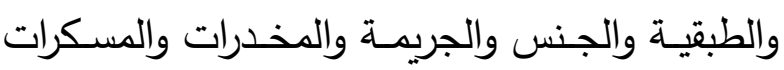

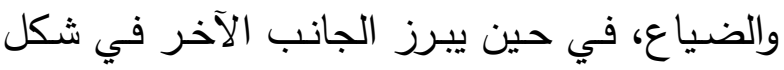
الغرب الحضاري الانبهاري والإيجابي الذي يصور : الحب والحرية والحلم والمدنية... اللاوعي: يمكن رصد ملامسح اللاوعي في روايات متعددة تبحث في اللاشعور القومي والوطني عبر الشخصيات والأحداث. فبعض هذه الروايات تبحث عن الذات العربية وتدافع عن قضاياها وهويتها إذا مـا تحـثت عـن الـذل والظلـم والاسـتعمار والقهـر والسلطة... وهذا مـا يتضـح في الروايات المغاربيـة

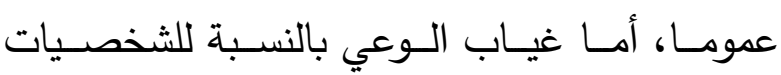

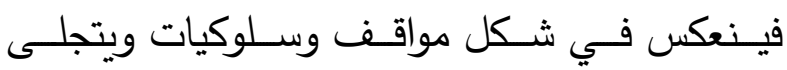
المظهر الفكري لغياب الوعي في وظـائف متباينـة

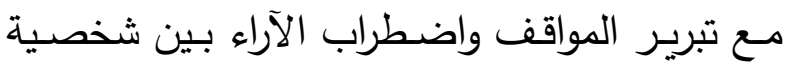

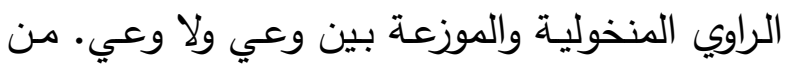

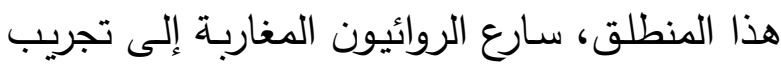

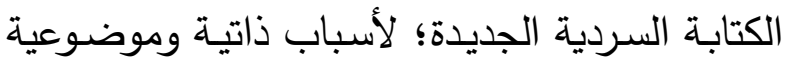
منها: ا ـ المثاقفة مع الفلسفة الغربية وآدابها: قراءة وترجمة وكتابة وتتلمذًا ... 


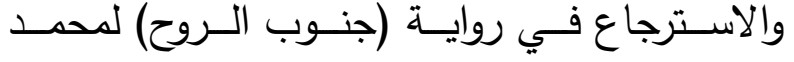
الشـعري. لقـــ نتجـت هـذه الظـاهرة التجريبيـة عـن المثاقفة والاقتباس والتأثر بالرواية الجديدة عموما في الغرب والرواية العربية اليوم. تداخل الشخصيات وازدواجها: تتداخل شخصية بطل الروايـة عمومـا مـع شخصية المؤلف نفسـه في كثير مـن المواقف عبر الزمـان والمكــان، والبطـلـل أو الـراوي هنــا ذا مكانــة فريـدة ومحورية في سير أحداث الرواية وتسييرها واستخدام تقنية الإسقاطات والاستفادة من الرموز الأسطورية كل حسـب مـا يـراه مناسـبا لمدلولاتهـ. وهذا مـا بـرز فعلا في تقنيات الرواية المغاربية المعاصرة بالذات. تـــاخل الخطابــات : يعـد تـداخل النصـوص أو مـا يسـمى بالروايــة داخـل الروايــة أو مـا يسـمى فـي المغرب العربي بالتناص في الأدب رافدًا من روافد

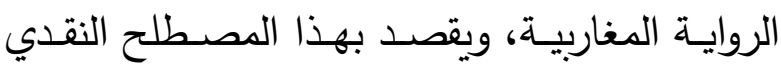
وجود تشـابه بين نص وآخر أو بين عدة نصوص، ويقـال فـي اللغــة تتـاص القـوم أي ازدحمــوا. أمــا كمفهوم، فهو تداخل نصوص أدبية مختارة قديمة أو أو أودون حديثة شعرا أو نثرا مـع نص آخر أصسلي، بحيث

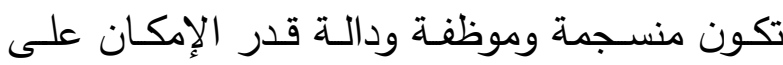
الفكرة التي يطرحها كاتب ما. أمـا بدايـة البحـث حـول التــاص فكـان مـع جوليـا كريسـتيفا (Julia Kristeva) عـام 979 (م، عنـدما Mikhail ) درســـ كتابــات ميخائيـلـل بــاختين Bakhtine)، عـن الروائـي الروسـي دوستويفسكي (Dostoïevski) نمطَا لدراسـاته ولكنـه اكتفـى "بتعدديـة الأصــوات".
ومسن أهـم خصــائص الروايــة المغاربيـة التجربيــة تـداخل الأزمنــة؛ إذ تـداخل الحاضـر مـع الماضـي والمستقبل في شكل تداعيات وأحسلام واسترجاع كما نجد في روايـة (رفقة السـلاح والقدر ) لمبارك ربيع، و(أوراق) لعبــد الله العـروي، و و(زمـن بـين الـولادة والحــم) لأحمـد المـديني، و(حـاجز الـثلج) لسـعيد علوش... يلاحظ كذلك "شعرنة" إذ يتـداخل المحكـي السـردي النتري مـع الخطـاب الثـعري كمـا في كتابـات محمـد عز الدين التازي (المباءة) وأحمد المديني. وتستخدم الأجناس الأدبية داخل الرواية لدى محمد برادة في (الضوء الهارب)

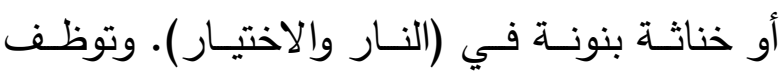
الرواية المغاربية تقنية الهوامش كما عند العروي في

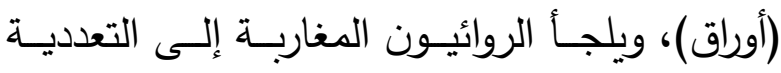
الأسـلوبية واللغويـة وتتويـع الأجنـاس كمـا في روايـة (لعبة النسيان) لمحمد برادة. تسـتـدعي الروايــة الجديـدة القصاصــات الإذاعيــة والإعلانيـة، وكـذلك أسـطرة المحكي السـردي في رواية (بدر زمانه) لمبارك ربيع، والتركيز على تقنية المستخ العجائبي في (أحلام البقرة) لمحمد الهرادي، رونا، و(سماسرة السراب) لبن سالم حميش، وفضـح أسرار اللعبـة الروائية كما في (لعبـة النسيان) لمحمد برادة

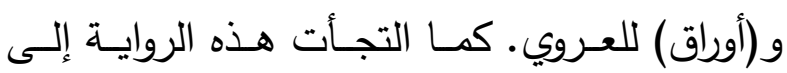
التشظية والخراب الروائي في كثير من النصوص، ووظفت التخييـل في (الخبز الحـافي) و(الشـطار) لمحمــ شـكري، و (الرحيـل والألـم) للعربـي باطمــا،

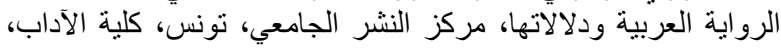

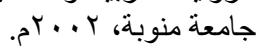


وللعودة لبارت، عُفإن النص عبارة عن نسيج من الاقتباسات والإحالات والأصداء من اللغات الثقافية السـابقة أو المعاصرة التي تخترقه بكامله، والتتاص هو تفاعل أنظمة أسلوبية من حيث التلميح والإيماء المتعلق بالموضوع، وهو من أهم الأسـاليب النقديـة

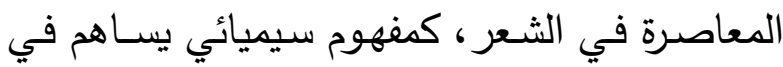

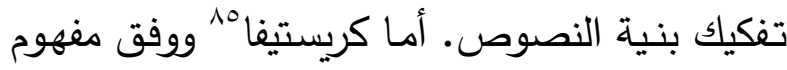

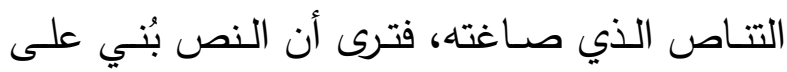

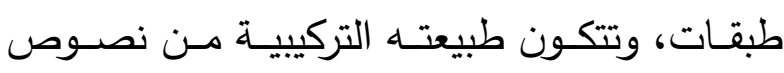

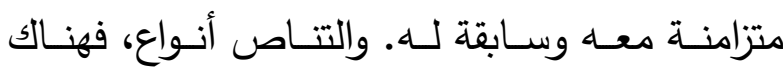

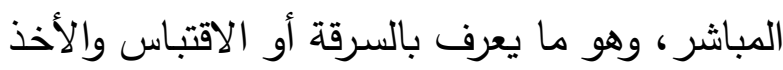

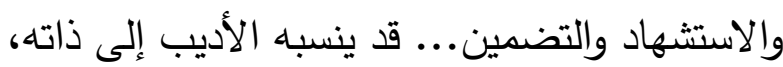
كما قال الأخطل: نحن الشعراء أسرق من الصاغة. وهنـالك تتـاص غيـر المباشـر ، كـالتلميح والتــويح

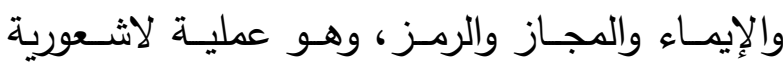
يستتتج الأديب من النص المتداخل معه أفكارا يرمز إليها في نصها الجديد. لقـــ شـاع التــاص في في الأدب الغربـي قبـل الأدب العربي وتأثر الأدب المغاربي الذي وصلت إليه هذه

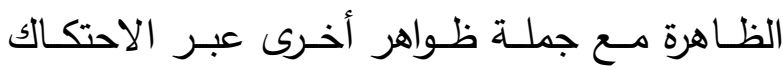

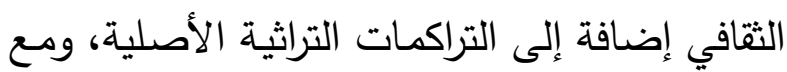

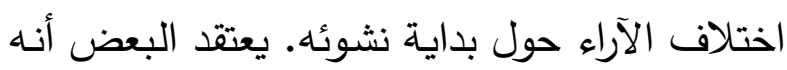

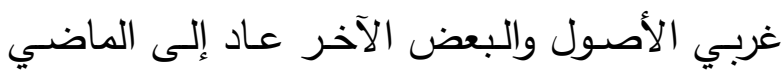

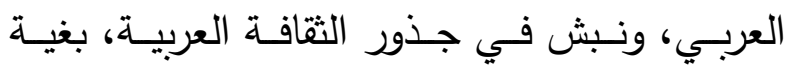

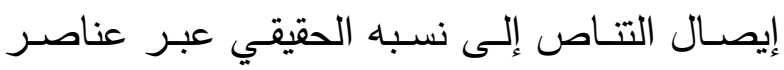

${ }^{84}$ Roland Barthes, Le plaisir du texte, Paris, Point essais, 1973-1982.

85 Julia Kristeva, Séméiotiké, Pour une sémanalyse, Seuil, Paris, 1969.

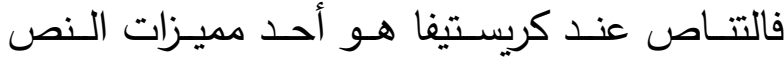

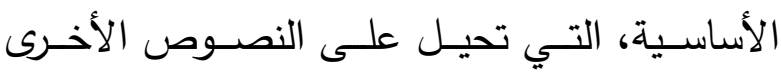

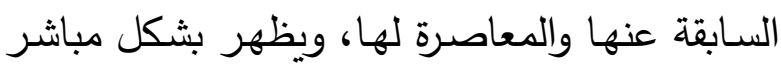
مع التحليلات التحويلية في النص الروائي عندها ولفها. ومصطلح التناص مأخوذ في جوهرة من المصطلح الفرنسي (intertext) وهي كلمة مقطعة: (inter) تعني بالفرنسية التبادل، بينما كلمة (texte) تعني وفئي النص، وأصل الكلمة كلها مشتق من الفعل اللاتيني

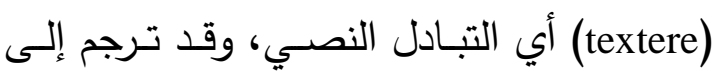

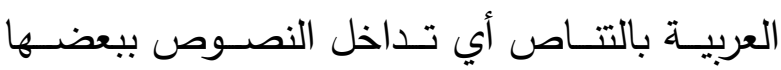

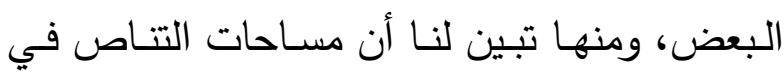

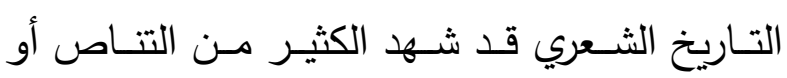

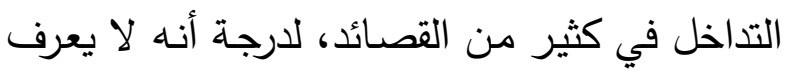

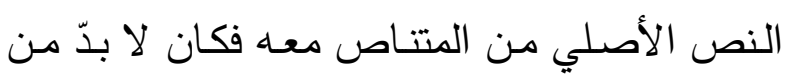

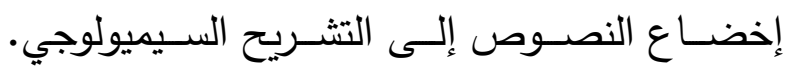

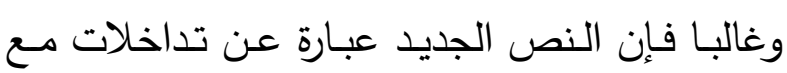
نصوص سـابقة، الثرط فيها وجوب الاختلاف وإلا

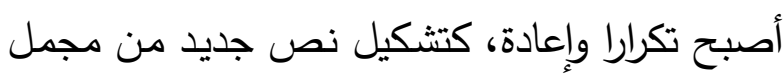

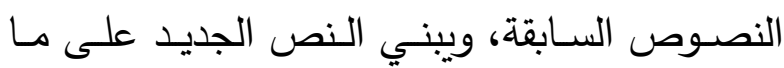

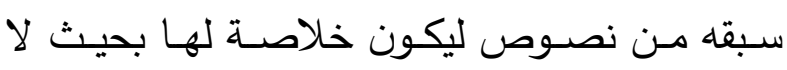

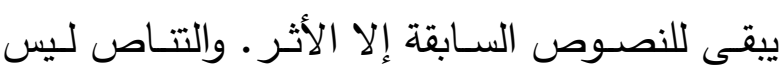

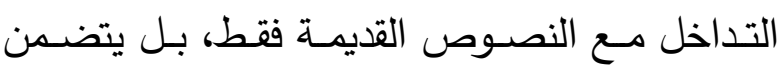
مفاهيم قادرة على استيعاب النصوص الجديدة. إذا

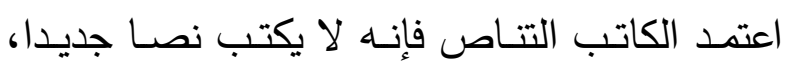

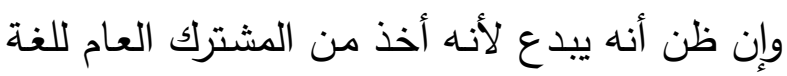

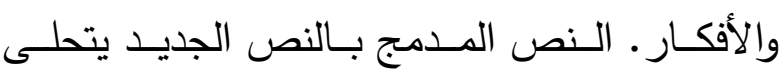

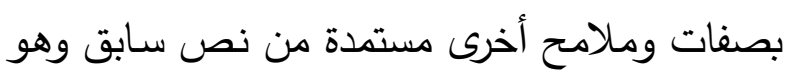
ثمرة نصوص مختزنة في الذاكرة الإنسانية. 
بعد، وهو العدم الذي سيصبح وجوداً بعد اختفـاء الحاضـر ، وتحولـه إلى الماضـي. والزمــان عنصـر رئيسي مـن عناصـر تكـوين الروايـة، وهـو نوعـان: زمـن خـارج الـنص، وهـو زمـن موضـوعي، وزمـن داخل النص وهو زمن تخييلي انفصـم عن الزمـان الموضـوعي، وتـداخل مـع النسـيج الروائي. لتـداخل النصــوص. ولـــه أهميـة كبيـرة فـي بنـاء الـنص الروائسي، إذ يحـد عوامـل فنيـة مرتبطــة بالخطـاب الروائي كانتقاء الأحداث وترتيبها، والإيقاع وطريقة السـرد... يحمل كل عمل فني بنيـة زمانيـة وأخرى مكانية، الأولى تعبير داخلي والأخرى مظهر حسي، تتلاحم البنيتين وتشكلان إبداعا وعمـلا فني. يقول زكريـا إبراهيم عن هذه الحقيقـة الفنيـة: "لابـد للعمل الفني مسن بنيـة تعـد بمثابـة المظهر الحسـي الذي يتجلى على نحوه الموضوع الجمالي، كمـا أنـه لابد من بنيـة زمانيـة تعبر عن حركته الباطنيـة ومدلوله الروحي بوصفه عملاً إنسانياً حياً". 19 يرتب الروائي أحداثه ترتيباً تاريخياً، لا مجـال فيـه

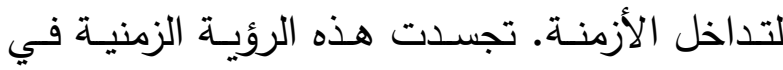
رواية زينب لمحمد حسنين هيكل ـ وهي أول رواية

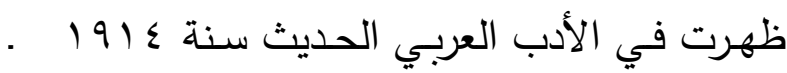
حيث نجد "زينبب" فتاة ريفيـة جميلـة تحب "إبـراهيم

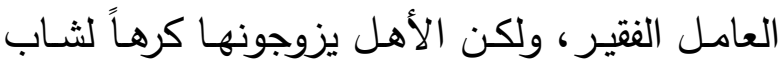
آخر يدعى "حسن"، ويمضي الزمان بالأحداث في هذه الرواية في اتجاه طولي رتيب مألوف، لجأ إليه الكاتب للمحافظة على السياق التاريخي دون تقديم أو تأخير

"199 زكريا إبر اهيم، مشكلة الفن، مكتبة مصر، القاهرة (د.ت)، ص YV.
الاتصـال المألوفـة: المرسـل، الرسـالة، المرسـل إليـه. والأكيد أنسه لا يمكن للأديب أن ينفصل في تكوينه الثقافي الأدبي عن غيره، لأن الحقل المعرفي لأيّ أديب يتكون عبر التواصل المعرفي. فالتناص هو الحوار الواقع بين الكتابات المختلفة التي تقع للكاتب قبل كتابته أو أثناءهـا شـعوريا أو لا شعوريا. وممـا سبق فان كتاب المغرب العربي يمثلون في كتاباتهم هذا التناص. تــاخل الأمكنــة: الأمكنـة عبـارة عـن فضـاء رمـزي وفضاء واقعي، فالمكان بالنسبة لها مكان جغرافي، بل هو حالة ذهنية أو فكرة يتوسل الكاتب لإيحائها وبث الحياة فيها بكل ما يمكن أن يعيينه على إعادة بنائها وتثبيتها في الذاكرة مستخدما وسيلته اللغة. واللغـة وسيلة تواصسل وأداة تعبير وهو نتيجة حركة

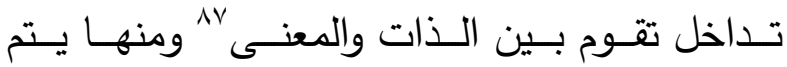
استرجاع ذكريات قريبة أو بعيدة لا تخالف في كل الحـالات "إعـادة إنتـاج الواقـع المحسـوس بواسـطة

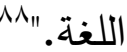

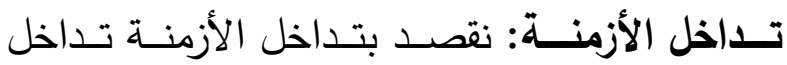
الحاضـر مـع الماضـي، وبعبـارة أخرى ننقل الزمـان بحركته اللامرئية بين ثلاثة أبعاد: الماضي وهو ما

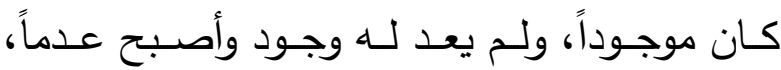
والحاضــر وهـــو الوجــود والــرابط الحقيقــي بــين (الماضـي) و(المستقبل)، والمسـتقبل الذي لـم يوجد

، ^د د. بشير بويجرة محمد، بنية الزمن في الخطاب الروائي ، الجزائري

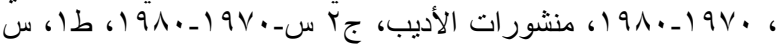

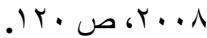

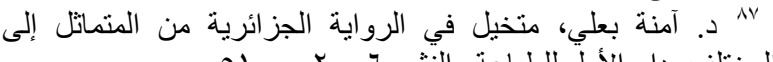

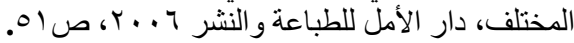

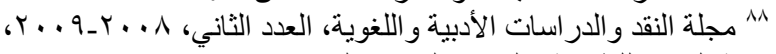

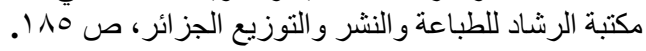


الروايـة المغربيـة وجودهـا ضـمن أجنـاس الإبـداع

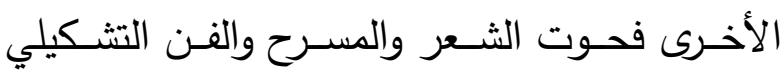

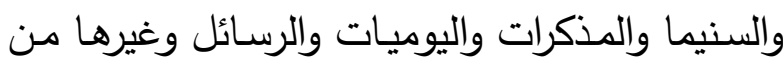

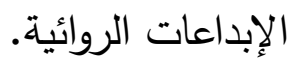
تعدد الاصسوات السردية: تسمى الرواية الكلاسيكية

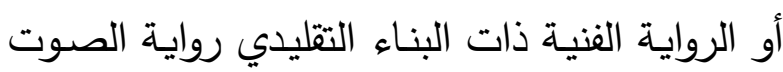

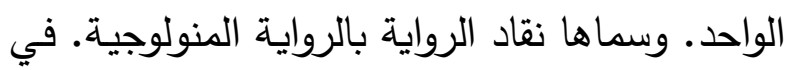
حين، لم تظهر الرواية البوليفونية المتعددة الأصوات إلا مع دوستفيسكي (Dostoïevski)، حسب المنظر الروسي ميخائيل باختين (Mikhail Bakhtine). تعتمد الرواية البوليفونية على تعدد المواقف الفكرية، واختلاف الـرؤى الإيديولوجيـة، وترتكز على كثرة الشخصيات والرواة والسراد والمتقبلين، وتستتد إلى الصى

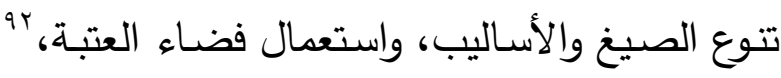

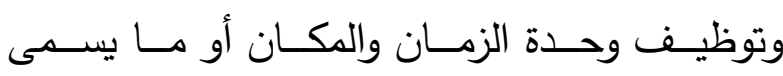
بالكرونوتوب (Chrono tope)، وتشغيل الفضـاءات

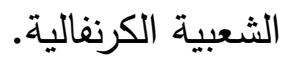
البوليفونية (Poliphonie)، هي لغة تعدد الأصسوات،

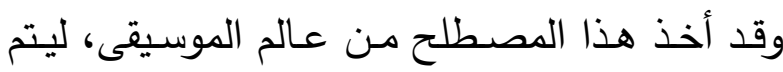

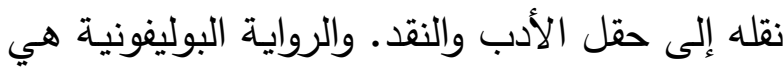

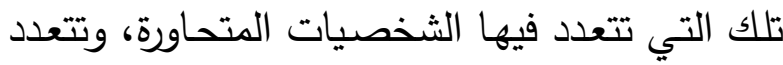

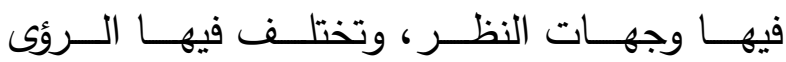

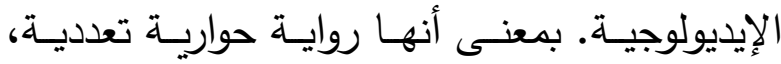

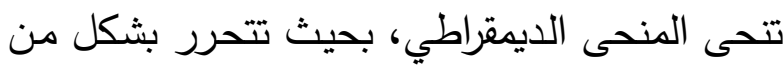

rو الفضاء أو العتبة (Seuil) في الرواية البوليفونية، هو مقر الصدمات

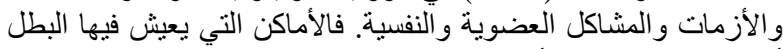

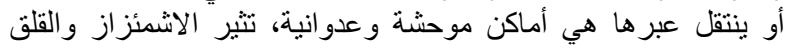

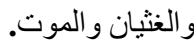

ومـع تطور الروايـة الحديثة، تطور مفهوم الزمن

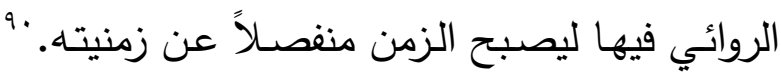

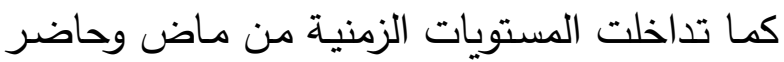

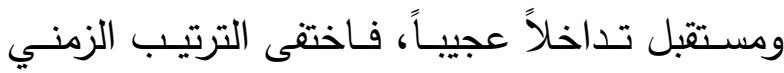

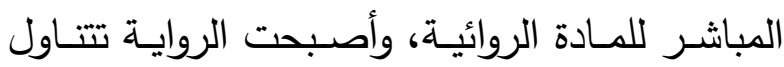

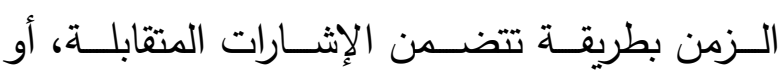

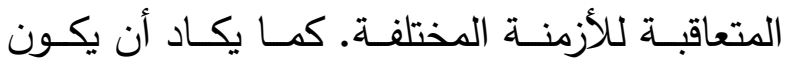

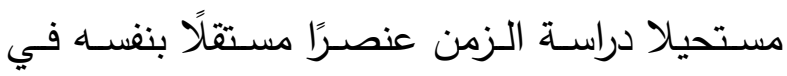

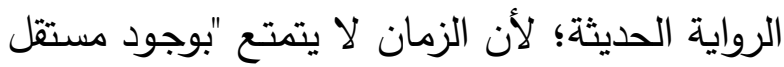

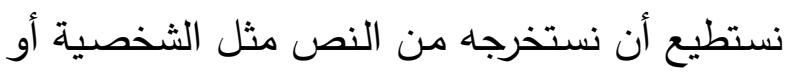

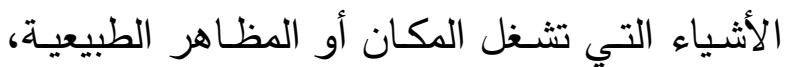

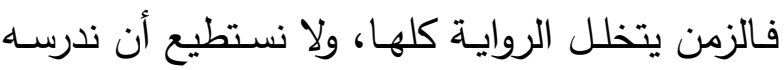

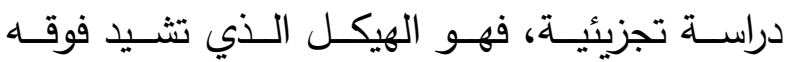
الرواية"." ومن هنا، تأتي أهميته عنصرًا بنائيًا يؤثر في العناصر الأخرى وينعكس عليها. تداخل الأجناس الأدبية في الرواية المغاربية:

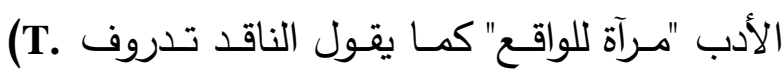

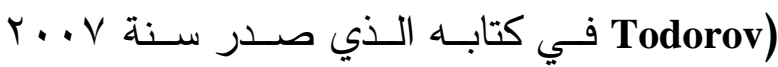
بعنوان: "الأدب في خطر"، لقد شـرح تدروف قيمـة

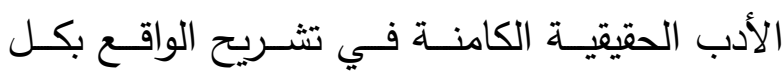

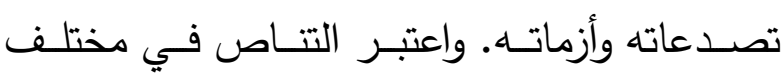
أنواعه وتشكلاته تقنية استفاد منها الكثير من كتاب واتهات

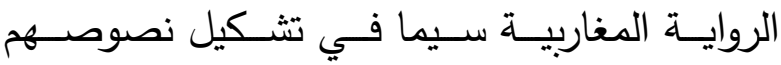

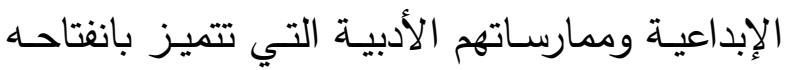

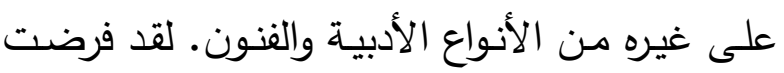

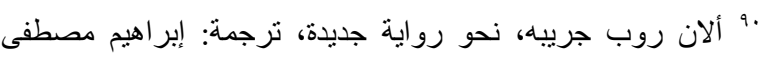

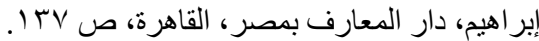

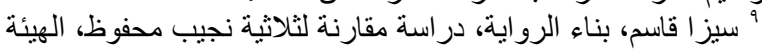

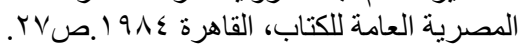


تعـدد اللغـات والخطابـات: المقصـود هنـا هو تعدد سجلات الكلام، كلغة الحديث اليومي التي تتخللها في الغالب لغة السرد الفصيحة، وهناك لغة المهنيين الدارجة ومصطلحاتهم، ولغة النقد الروائي كالتقنيات والمصطلحات التي يستخدمها الراوي، ولغـة الكتابـة كالرسائل التي تكتب داخل الرواية، واستخدام اللغـة الأجنبيـة أو مصسطلحاتها كواقع لغوي، يتضـح عند الكتـاب والنقـاد في بعـض بلــان المغـرب العربـي ويعيشه المواطن في حياته اليومية. موت المؤلف وبعث القارئ: يعود الفضل في ظهور فكرة موت المؤلف في النقد الروائي في فرنسـا إلى الناقد الفرنسي رولان بارت في الستينات من القرن العشرين (Roland Barthes) حيث وضـع حدا لحضـور المؤلف في الرواية لكي

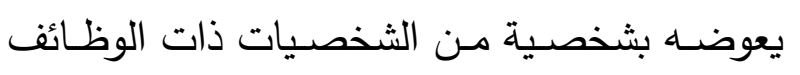
الجمالية التي كان يقوم بها. يفيد موت المؤلف أو لوتئ غيابه في عدم تدخله في النص، وبالمقابل ينتقل القـارئ مسن الهـامش إلـى الـصن، ويصـبح ذا دور

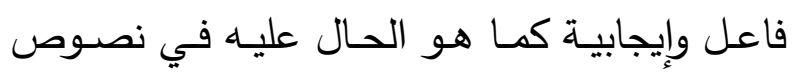
روايتي الكاتبـة الجزائريـة أحـلام مستغانمي: فوضـى هـ

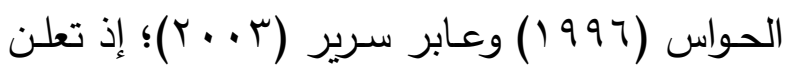
شخصية صـاحب الثوب الأسـود عن قتلهـا للكاتبـة

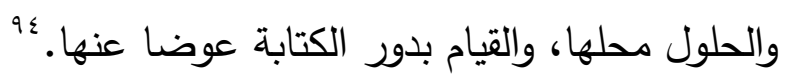
تشظية النص الروائي المغاربي: استخدم جيل الثمانينات من كتاب الروايـة المغاربية تشظية النص تقنية روائية، وقد استمدوها من جيل § أنظر: د. بوشوشة بن جمعة، سردية التجريب وحداثة السردية في

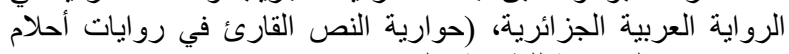

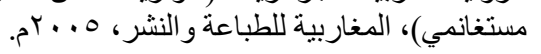

الأشكال من سلطة الراوي المطلق، وتتخلص أيضـا من أحادية المنظور واللغة والأسلوب. ومـن الظــواهر الفنيـة التـي تتبنـي عليهـا الروايــة

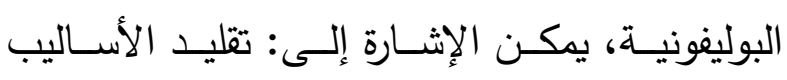
(Stylisation) كذلك بالبارودي (Parodie)، والحوار (Dialogue)،

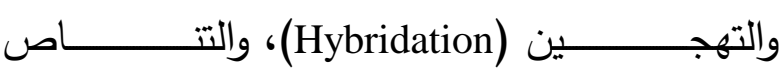
(Intertextualité) والأجناس المتخللة.... تعدد الرواة: يتعدد الرواة بناء على ما يتعامل معه

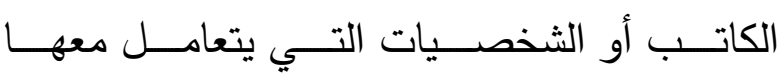
كشخصيات ارتبطت يوما ما بحياته. لكل شخصية

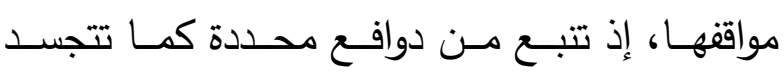

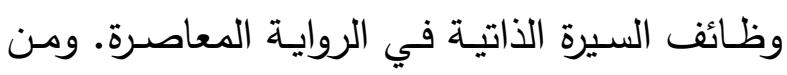
أهـ النصـوص الروائيـة الممكنـة في هذا المجـال،

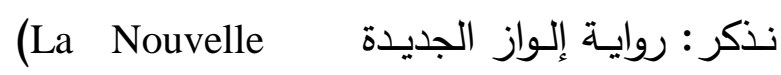

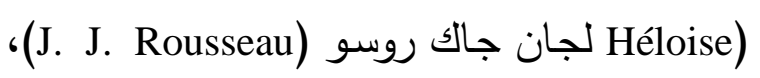

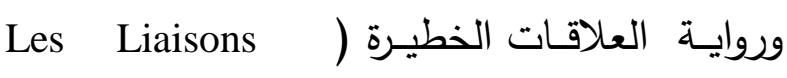
Choderlos (Dangereuses

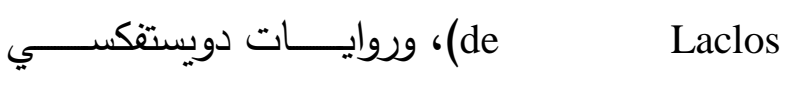

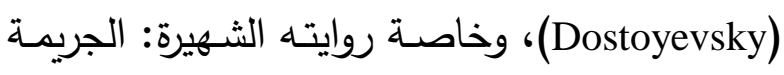
والعقــاب (Crime and Punishment) ومــن أهـــ ونـ الروايـات العربيـة المغاربيـة التي سـارت على هــا النحـو، نــذكر علـى سـبيل المثـال: روايــة (لعبــة

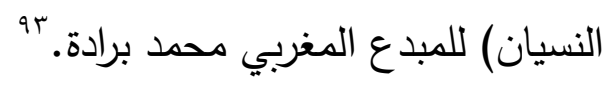
r بَ" محمد برادة، لعبة النسيان، دار الأمان، الرباط، المغرب، طبعة، 
أو منفى أو الهجرة انتقالًا من مناطق نائية إلى مدن

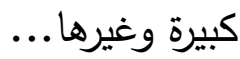
مواقف الكتاب: يقوم الكتاب بدراسـة لبعض الأدباء وشخصـياتهم، ويحلـل النقـاد أعمـالهم ويستعرضـون بعض المواقف من حياتهم، وغالبا ما يتحدث الكتاب في موضـوعات متشـعبة ومختلفـة كالثـعر والأدب والتاريخ واللغة والفن.... الموقـف مـن الكتابــة: الكتابـة هـي ذاكـرة الفعـل والإحساس، وغالبا ما يتم الاهتمام بشكلها الإبداعي بصـرف النظـر عـن التصـنيفات التي أفرزهـا النقـد الحديث، فالمؤلف يكتب لكي يفرغ شـنة عاطفيـة يشعر بها القارئ والناقد، فالكتابة سرية، لذا فالجميع يقوم بعمليـة تخزين للمواقف على مستوى الذاكرة والمشـاعر ، وهذا التخزين ينضـج مـع الوقت ليتحول إلى أداة تعبير ، وأداة التعبير هذه هدفها في الأسـاس "التفريخ"، فحين تتحدث لصديق عن هذا الموقف أو ذلك، أو حين تبكي تأثراً به أو بغيره، أو تقوم بفعل ما فإنك تنفس عن حالتك التي تشعر بها. الموقف مسن الروايـة: لا شك أن للكتاب المغاربـة موقفا إيجابيا من الروايـة كونها أسهمت في الوعي

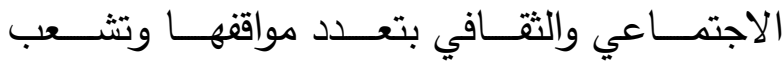
مواضيعها التي طرحت لكي تحكي الآمها وتحاكي مثيلاتها سيما في الوطن العربي. إن حضور الحريـة في تشكيل النص الروائي المغاربي عنصر أسـاس إس إس في قوة حضور إبداعات الكتاب المغاربة وتوهجها ، فهي بـذلك تحطم كل الحدود وتتجاوزهـا، وهذا مـا تؤكده مارت روبير (Marthe Robert) في قولها إن للروايـة مطلق الحريـة "في اختيـار مواضيعها وأطر
السـتينات مسن كتـاب الروايـة الجديـدة في مصـر كادوارد الخراط، ويوسف القعيد، وجمال الغيطاني، وصـنع الله إبراهيم، وإبراهيم أصـالان وغيرهم وكذلك من كتابات أعلام الرواية في فرنسا في الخمسينات Alain ) من القرن الماضي مثل: الأن روب غرييه

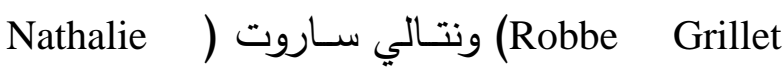
(Sarraute وميشيل بوتور (Michel Butor) وغيرهم من الـروائيين البـاحثين عن أفق جديد في الكتابـة الروائية. والتشظية تحول وحدة النص إلى شتات من خـلال تقطيعهـا إلـى مقــاطع تتـداخل فيمـا بينهــا: كاضــافة الحكايـات والخطب والثـعر أو المضـامين أو الحكم والأمثال.... وتسـهم التشـظية أو تفتيــات النص ومكوناته في تشعب السرد إلى حد التيه في

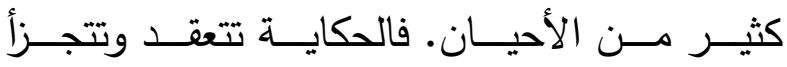
الشخصيات والأحداث والخطابات ولغة السرد. تشكيل النص: نعني بـه إعطاء شكل وهيئة تشغل البصر وتثير معنا متحركا في ذهن المتلقي، دون اهتمام لمطابقة المفهوم لما يسمى بالفنون التشكيلية (Art plastiques) الثفوي والتعبير بالصورة. فالخطوط تمثل الأصسوات واسترجاعها يمثل الوظيفة أي ما تحول إلى صنعة بصرية جمالية. معالجــات الروايــة: يتطـرق الكاتب المغــاربي ذو التعبيـر الفرنسـي إلى مواضسيع تهـتم بـالهجرة واقعًا

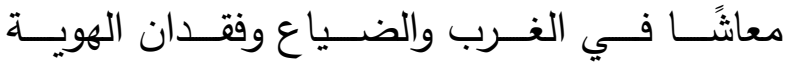
والسياسة.... وكذا لمن كتب ويكتب بالعربية، الجميع يعالج قضايا واقعية يعيشها الفرد المغاربي في حياته اليومية كالفقر والفساد الإداري والهجرة مصدرًا للرزق 


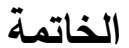

يعد الإبداع الروائي المغاربي، الحديث والمعاصر ، أدهاء

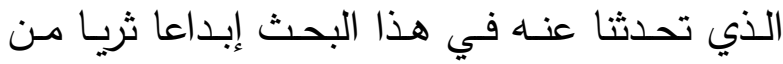
خـلال التجــارب والخصوصـية والمواكبــة وتعـدد إشكالياته. نشأ ذلك نتيجـة المعاناة التي يثعر بها ولها

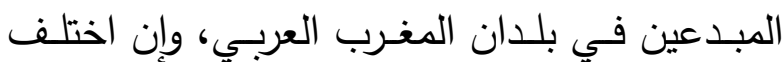
الزمان والمكان. ويتضح للعيان من خلال النصوص

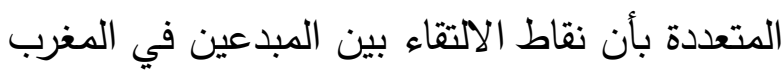

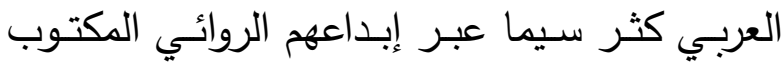
باللغتين: العربيـة والفرنسية. ذلك كون كلا اللغتين المكتوب بهما الإبداع، تعكس في جوهرهما، مسألة

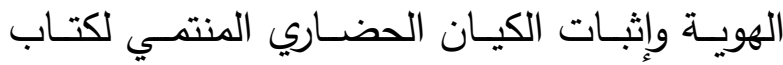
الرواية عبر ما يجسدونه من طرح إشكاليات متعددة

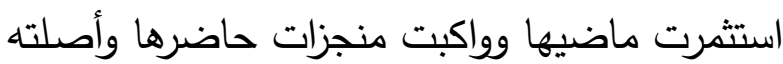

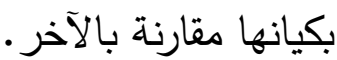

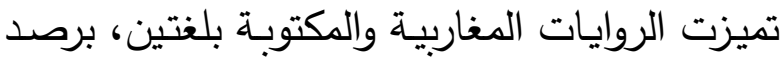

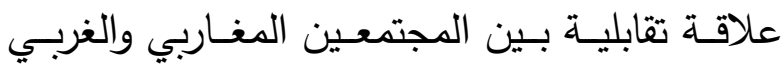
وأخرى قدمت صورة عن الواقع الاجتماعي والفكري

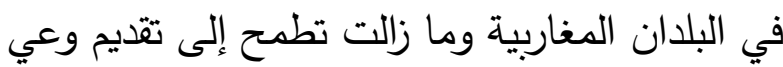
شـامل بقضــاياه وخصوصـا في علاقتـهـه بحضــارة

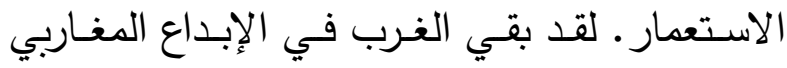

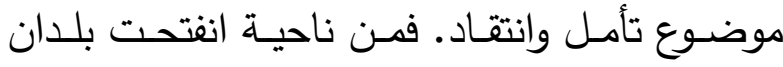
ومجتمعات المغرب العربي على الغرب كمـا يؤكد عباس الصوري: "عن طريق التعليم وأجهزة الإعلام

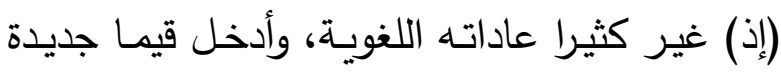
تتعارض مع ما كان للعربية من قداسة وتقدير ثقافي وميل إلى تقليد السلف في بلاغتهم التقليدية، ودعا لفاليا
أحداثها وطرق تصـوير الواقع، رافضـة كل القواعد، مخترقة كل الحدود."90 الموقف من الثالوث المحرم: بحـرت الروايـات المغاربيـة المكتوبــة بلغتـين إلـى

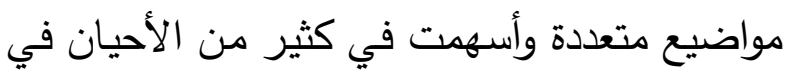
الثورة الثقافية والعلمية والوعي الاجتماعي في العالم

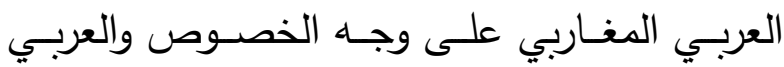

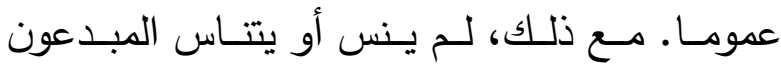

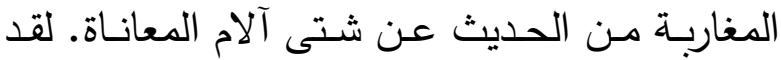
كان لحدة الطرح أحيانا، جرأة خارقة للقوانين وتثكيل

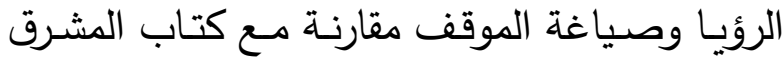

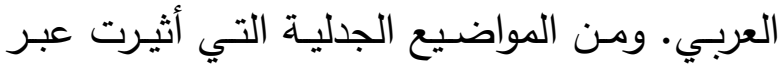

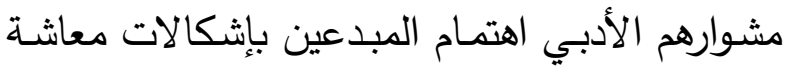

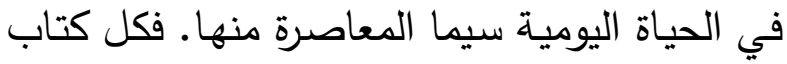

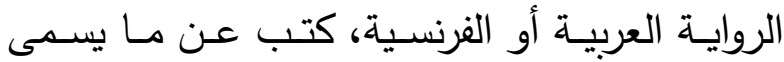
بالثالوث المحرم: الدين والسياسـة والجنس وبنفس القدر • وغالبية من وظف هذه المواضيع من الكُتاب

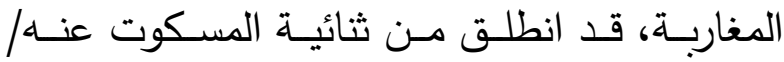

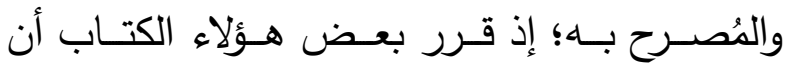

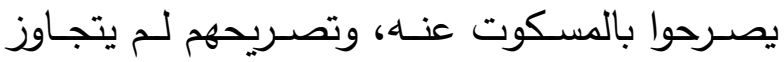
مستوى التلفظ الخطابي. مستبعدين الاشتغال الفني على استثمار تلك المواضيع (التيمـات) في توليد الدلالات والتأويلات الخطابية وصهرها ضمن نسيج حكائي متتام بمستواه البنائي أو الدلالي أو التمثيلي

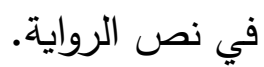

\footnotetext{
${ }^{95}$ Marthe Robert, Roman des origines et origines du roman, coll. "Tel", Paris, Gallimard, 1976, p. 15.
} 
تجاوزوا ذلك كونهم أصحاب فكر يقض وناقد سيما في حديثهم عن القضايا المغاربية الصرفة. كما نجد في الأدب المغـاربي المكتوب بلغتين، سلسـلة مـن

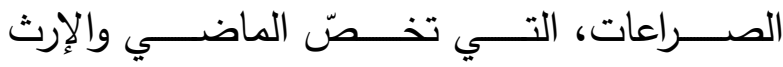
الاستعماري والتقاليد، مقابل خطاب التحديث والحرية والليبراليـة، والرمزيـة التي تتــاول موضـوعات القيم

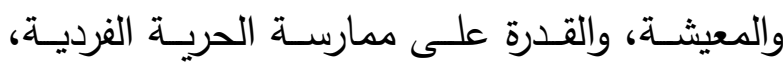
والثغف بالهوية بوصفها وجودا اجتماعيا لـه خياراته

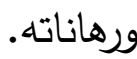
تعرفنا الروايـة المغاربيـة عبر معطياتها على محنـة الحروب المهددة التي عاشها الإنسان العربي عموما

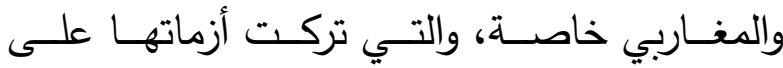
المجتمـع المغـاربي ممثثلا في الرجل والمرأة، وعلى الوعي وأثره النفسي الذي تركه الاستعمار والاحتلال والأزمسة الفلسـينية وحرب الخليج والربيـع العربـي وغيـره مـن الأحـداث. كمـا حققت الروايـة المغاربيـة مشاهد إبداعية متعددة. وأثثتت العديد من الدراسات أهميـة مـا تمثلـه هـه الروايـة وترسـخه في التفكيـر النقدي الممثل في أســاء كتابهـا وتجـارب النتـاد البارزة، لقد رسـخت الوعي المعرفي بالنقد الروائي من خلال مناهجه وتصوراته ومفاهيمه. 91 كمـا يوضـح البعد الحواري للروايـة المغاربيـة قدرتها على بناء خصوصيتها وجديتها ومكانتها ويسهم في بنـاء صسياغة تصسورها الإبداعي وهاجسها التجريبي داخـلـ نطـاق جنســها الروائـي. وتحمــل الروايــة

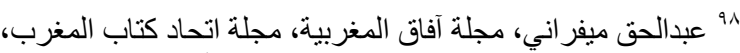

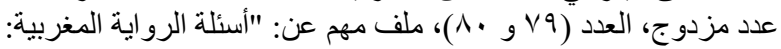

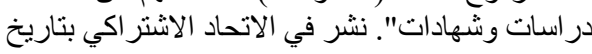
د. $11 / \cdot \varepsilon / r 7$
إلى خلق أنماط أخرى مـن التعبير ومفاهيم جديدة

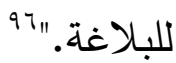
كمـا أن النـــاذج الروائيـة التـي أشـرنا إليهـا عبــر دراستا دلائل على تواتر صور الالتقاء التي تبرز عبـر الإبـداع المغـاربي المكتـوب بلغتين. إذ جســـ الإبـداع المغــاربي المنفتح والـواعي بكل مـا يجـري حولـه، علاقتـه بذاتـه كمـا جســ الآخـر موضـوعًا للنقاش، وهذه العلاقـة "حددتها التطـورات السياسـية والتحـولات الاجتماعيـة والاقتصـادية والثقافيـة التي شـهدتها بلدان المغرب العربي في تاريخها الحديث والمعاصـر ." "هذا تعددت الخطابات والصيخ في الرواية الواحدة بتعدد الأحداث والحكايات والإشارات والرسائل التي تسهم في إضاءة الحدث وتقديمه. عكسـت الروايـات المغاربيـة أيضـا، مواقف انتقاديـة تجـاه واقع مجتمعها المغـاربي وحصـرتها في وجود فوارق اجتماعية مختلفة وطبقات، وفي انعدام الحرية والتبعيـة للمستعدر والحرمان بكافة صورو المعيشية والجنسية وإشكالية الأرض وأزمـة الفكر وواقع المرأة والتفكيـر الخرافي وعنف السـلطة، والهيمنـة الثقافيـة

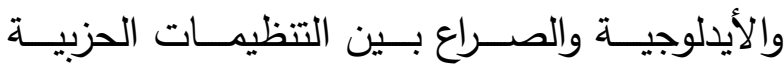
والنقابية.... تنم كل هذه المواقف عن وعي الكاتب المغـاربي وتعـدد مواقفـهـ الأيدولوجيــة المباشــرة. والمبـدعون المغاربة دن الجنسين، دائمو الحذر ولم يحدث عبر رواياتهم، أن وقعوا في تصـورات ثابتة ونهائية، بـل

19 ${ }^{9}$ عباس الصوري، تعليم التواصل، أقلام (المغربية)، عدد ؟، أكتوبر

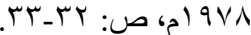

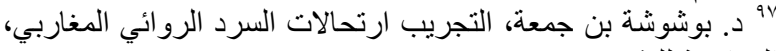

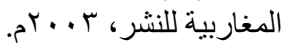


د. بوشوشة بن جمعة، سردية التجريب وحداثة السردية في الرواية العربية الجزائرية، المغاربية للطباعة والنشر ، 0 . . بم. • د. بوشوشة بن جمعة، مختارات من الرواية المغاربية المعاصرة، الجزء الأول والثاني، بيت الحكمة، قرطاج، ب 99 ام. د. بوشوشة بن جمعة، إتجاهات الرواية في المغرب العربي، المغاربية للطباعة والنشر

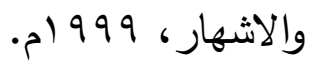
د. مصطفى عبدالغني، الاتجاه القومي في الرواية، عالم المعرفة، رقم ^^ (، سلسلة كتب ثقافية شهرية يصدرها المجلس الوطني للثقافة والفنون والآداب، الكويت، 99 (م.علامات في النقد، المجلد الرابع عشر الجزء سه، ؛ ...بم، الندي الأدبي الثقافي بجدة. •اكر نوري، منفى اللغة: حوارات مع الأدباء الفرانكفونيين، كتاب مجلة دبي الثقافية، عدد رء

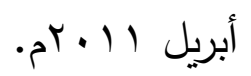

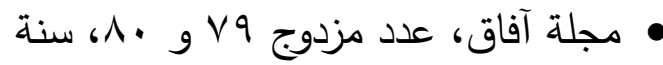
• 1 . بم، اصدار اتحاد كتاب المغرب. • مجلة آفاق، عدد مزدوج N N و $\cdot 0^{0} \cdot 14$
المغاربية في طياتها توازنًا راقيَّا بين الكتابة والحكاية وأصول الخيال، وتسير بتوازن بين مختلف وظائفها الجماليـة والمعرفيـة والتداوليـة في مختلـف أرجـاء المغـرب العربـي والعــالمي. وهكـذا أثرت الروايـة المغاربية الجديدة خيالنا وتعابيرنا وأبهرت النقاد حتى أصسبحت ذات اهتمــام متزايـد بعـد أن أجـادت فـن الحكاية لتصبح نصوصـا مفتوحة على العالم وعلى مواكبـة تحولاتـه. كمـا تعمل الروايـة المغاربيـة على ملى تشكيل مداخل أساسية في قراءة نصوصها الأدبية وتحليلها التي تربطنا بالنص وتأويله وبالعالم. 99 المراجع العربية

عبد الحميد عقار، الرواية المغاربية: تحولات اللغة والخطاب، شركة النشر والتوزيع، المدارس، الدار البيضاء، الطبعة الأولى ... . بم. د. حميد لحمداني، أسلوبية الرواية، منشورات دراسات سال، مطبعة النجاح الجديدة، الدار البيضاء، الطبعة الأولى سنة 9 أم. رشيدة بن مسعود، المرأة والكتابة: سؤال الخصوصية/ بلاغة الاختلاف، أفريقيا الشرق، الطبعة الأولى، ع99 (م. • حكيم عنكر، الرواية المغربية تتطق بلسانين، ملحق الخليج الثقافي، الرباط، تاريخ النشر: $\cdot r^{r} \cdot 9 / 1 \cdot / r \leq$ 


\section{المراجع الأجنبية}

- J. Déjeux, Le sentiment religieux dans la littérature maghrébine de langue française, éd. L'Harmattan, 1986.

- Marc Gontard, Le moi étrange: Littérature marocaine de langue française, Paris, L'Harmattan, 1993.

- Denise Brahimi, Appareillages, éd. Deux temps Tierce, 1991.

- Assia Djebar, Les Enfants du nouveau monde, Juillard, 1962.

- Assia Djebar, L'amour, la fantasia, éd. Albin Michel, Livre de Poche, 2001.

- Jauss. R., Pour une esthétique de la réception, Paris, Gallimard, 1978.

- Rachid Boudjedra, La vie à l'endroit, Paris, éd. Grasset et Fasquelle, 1997.

- Jean Mazel, Enigmes du Maroc, éd. Robert Laffont, 1971.

- Jean Palou, La Sorcellerie, Puf, Que sais-je ? 1ère éd. 1957.

- Jules Michelet, La Sorcière, éd. Garnier, Flamarion, 1966.

- N. EL-Sa'adaoui, La face cachée d'Eve, Paris, éd. Des femmes, 1982.

- Fatima Mernissi, Sexe, idéologie, Islam, Paris, éd. Tierce, 1983.

- Roger Chemain, L'imaginaire dans le roman africain, L'Harmattan, Paris, 1985.

- Michel Erlich, Les mutilations sexuelles, Paris, Puf, Que sais-je ? 1991.

- Germaine Tillion, Le harem et les cousins, éd. Seuil, coll. Point, 1966.

- Jean Libis, Le mythe de l'androgyne, L'île verte, éd. Berg / internationale, 1980.

- Ahlam Mostéghanemi, Femmes et écritures, Paris, L'Harmattan, 1985.

- Abdelwahab Bohdiba, La sexualité en Islam, Puf, 1975.

- T. Ben Jelloun, L'Hospitalité française, Paris, éd. Seuil, 1984.
- Tahar Ben Jelloun, (in) A ma mère, 60 écrivains parlent de leur mère, éd. P. Horay, Paris 1988.

- Jean Genet, (in) Le monde, 11 novembre 1979.

- Nathalie Sarraute, L'ère du soupçon, Idées, Gallimard, 1978.

- N. EL-Sa'adaoui, La face cachée d'Eve, Paris, éd. Des femmes, 1982.

- Tzvetan Todorov, Mikhail Bakhtine, Le Principe, dialogique, Seuil, 1981.

- Jean Ricardou, le nouveau roman, Edition Seuil 27, rue Jacob, Paris 1978.

- Article paru le 14 Janvier 1957, (in) Démocratie, $\mathrm{n}^{\circ} 2$ p. 10, cité par Itinéraire et contacts de cultures. V. 11, Littérature maghrébine, T. 2, L'Harmattan, 1990, pp. 58-59.

- Roger Chemain et Arlette Chemain Degrenge, Imaginaires francophones, Publication de la Faculté des Lettres Arts et Sciences Humaines de Nice, Université de Nice Sophia-Antipolis, Nouvelle série, No. 22, 1995.

- Cahiers Jussieu, $n^{\circ}$ 5, Les marginaux et les exclus dans l'histoire, Paris, Université Paris VII, U.G.E., 10/18, 1978.

- D. Chraïbi (in) Cahiers de la Méditerranée, Juin 989, $\mathrm{n}^{\circ} 38$, Université de Nice.

- M. Mammeri, entretien (in) «Confluent» $n^{\circ} 23 / 24$ Sept.-Oct. 1962, pp. 560-568.

- S. Garmadi, entretien (in) «Alif», $\mathrm{n}^{\circ} 1,1971$.

- Feraoun Mouloud, Journal, 1955-1962, Le Seuil; Paris,

- Kateb Yacine, La langue de Malek, (in) Nouvel Observateur, $\mathrm{n}^{\circ} 1157,1987, \mathrm{p} .87$.

- A. Khatibi, (in) Le Monde, 17 Décembre 1971.

- A. Khatibi, Interview, (in) Présence francophone, $\mathrm{n}^{\circ} 8$; Paris, printemps 1974.

- Abdelatif, Lâabi, Souffles, n 18, 1970.

- Cahier d'études maghrébines, colloque, no. 2, mai 1990.

- Ibla, Revue Tunisian, 1992, t. 56, no. 169.

- Le Dictionnaire, Le Petit Larousse illustré, 1987. 


\title{
The Crossing of Arabic and Francophone Writings in Maghreb Literature: Fiction as an Example
}

\author{
Dr. Abdullah Ahmed Alghamdi \\ Arabie Saoudite - Jeddah \\ Email: aghamdi6@kau.edu.sa \\ et \\ dr_ghamdi@hotmail.com
}

\begin{abstract}
. the fiction text is considered an artistic form that protects us from forgetting our existence. The literary text accommodates various narrative types. This is an indication of the cultural identity from a reader's perspective. Fiction is a relatively new literary domain in Arabic. Nonetheless, it received a relatively highly praised position in global and modern Arabic literature, more specifically in Maghreb and North African domains. One reason for the emergence of the cultural openness is the cultural change after independence which in itself was a result of literary text concerned with a new breed of intellect, both readers and writers. The North African culture transferred from spoken to written.

It must be noted that the location of these North African nations allowed them to meet various cultures and civilizations. It also gave them a priority to build a deeply rooted culture in different languages, cultures, civilizations including Arabic, Islamic, Berber and African, all of which coexisted with the European West during and after the colonization. These North African nations benefit from a genuine heritage that is deeply rooted in history. When written evidence is sought, we find texts written in both languages which never forgot about their Islamic Arabic heritage. The North Africans were split between two different cultures and a civilization each represents genuine values.

The examples of crossings in North African novels written in two languages share a number of features including criticizing the North African social reality and identifying its connection with the Western society in different forms. Even if many French scholars refuse to admit the Francophone literature is a North African effort that expresses itself even if written in the language of the occupier, some believe that North African literature in French should be as Arabic literature written in French.
\end{abstract}

